\title{
Palaeostress inversion in a multiphase deformed area: kinematic and structural evolution of the Çankırı Basin (central Turkey), Part 1 - northern area
}

\author{
NURETDIN KAYMAKÇI, ${ }^{1}$ STANLEY H. WHITE ${ }^{2}$ \& PAUL M. VAN DIJK ${ }^{1}$ \\ ${ }^{1}$ ITC, Hengelosestr 99, PO Box 6, 7500 AA Enschede, The Netherlands \\ (email:nuri@itc.nl) \\ ${ }^{2}$ Utrecht University, Earth Sciences Faculty, Budapestlaan 4, 3508 TA Utrecht, \\ The Netherlands
}

\begin{abstract}
The kinematic and structural evolution of the major structures affecting the Çankırı Basin, central Turkey, has been deduced from a palaeostress inversion study. Four palaeostress tensor configurations indicative of four-phase structural evolution have been constructed from the fault slip data collected from the Çankırı Basin. The first two phases indicate the dominant role of thrusting and folding, and are attributed to the collision between the Pontides and the Taurides, the proposed interface of which is straddled by the Çankırı Basin. Phase 1 occurred in the pre-Late Palaeocene and Phase 2 in the Late Palaeocene-pre-Burdigalian. The third phase is dominated by extensional deformation in the Middle Miocene. The latest phase has been active since then and is characterized by regional transcurrent tectonics.
\end{abstract}

Palaeostress analysis is the estimation of the principal stress orientations using fault slip data obtained by field measurements of the orientations of populations of fault planes together with slip data. Slip directions are generally inferred from the orientations of frictional grooves or fibrous lineations, termed slickensides (Fleuty 1974). However, they can also be deduced from the focal mechanism of earthquakes (Angelier 1984; Gephart \& Forsyth 1984; Carey-Gailhardis \& Mercier 1987) and from the orientations of mechanical twins in calcite (Lacombe et al. 1990, 1992).

A number of methods have been developed for the palaeostress inversion and the separation of stress tensors in multiphase deformation situations, following the initial graphical and numerical methods of Arthaud (1969) and Carey \& Bruner (1974), respectively. Graphical methods have been further developed by Alexandrowski (1985) (modified M-plane method) and Krantz (1988) (odd-axis method). However, they are only applicable if special conditions are fulfilled. For instance, the faults to be analysed using the M-plane method should have developed under uniaxial stress conditions in which two of the principal stress magnitudes are equal and are manifest, in plan view, in a radial or concentric pattern of faults. The odd-axis method is applicable in triaxial strain conditions where two pairs of conjugate fault sets develop and display orthorhombic symmetry. On the other hand, numerical methods are more robust and have been more widely used (e.g. see Angelier 1979, 1984, 1994; Etchecopar et al. 1981; Angelier et al. 1982; Armijo et al. 1982; Gephart \& Forsayth 1984; Michael 1984; CareyGailhardis \& Mercier 1987; Reches 1987; Hardcastle 1989; Gephart 1990; Marret \& Almandinger 1990; Fleischman \& Nemcok 1991; Will \& Powell 1991; Yin \& Ranalli 1993; Nieto-Samaniego \& Alaniz-Alvarez 1997).

All numerical methods are based on the Wallace (1951)-Bott (1959) assumption that slip occurs parallel to the maximum resolved shear stress and is also presumed to be parallel to the slickenline direction. A further assumption is that a given tectonic event is characterized by one regional homogeneous stress field. This implies that the slip direction on a fault plane is determined by a single-stress deviator and that all faults which slipped during one tectonic event moved independently but in a way consistent with this single-stress deviator (Will \& Powell 1991). After determining the stress tensor with respect to operative fault planes, it is transformed to a regional coordinate system using standard computational transformations (Means 1976; Angelier 1994).

The assumptions upon which the numerical methods are based are an oversimplification of the situation encountered in the field. Inhomogeneity and anisotropic material properties, fault interactions (especially in strike-slip settings), the presence of rotational deformation, and the non-coaxial stress and strains 

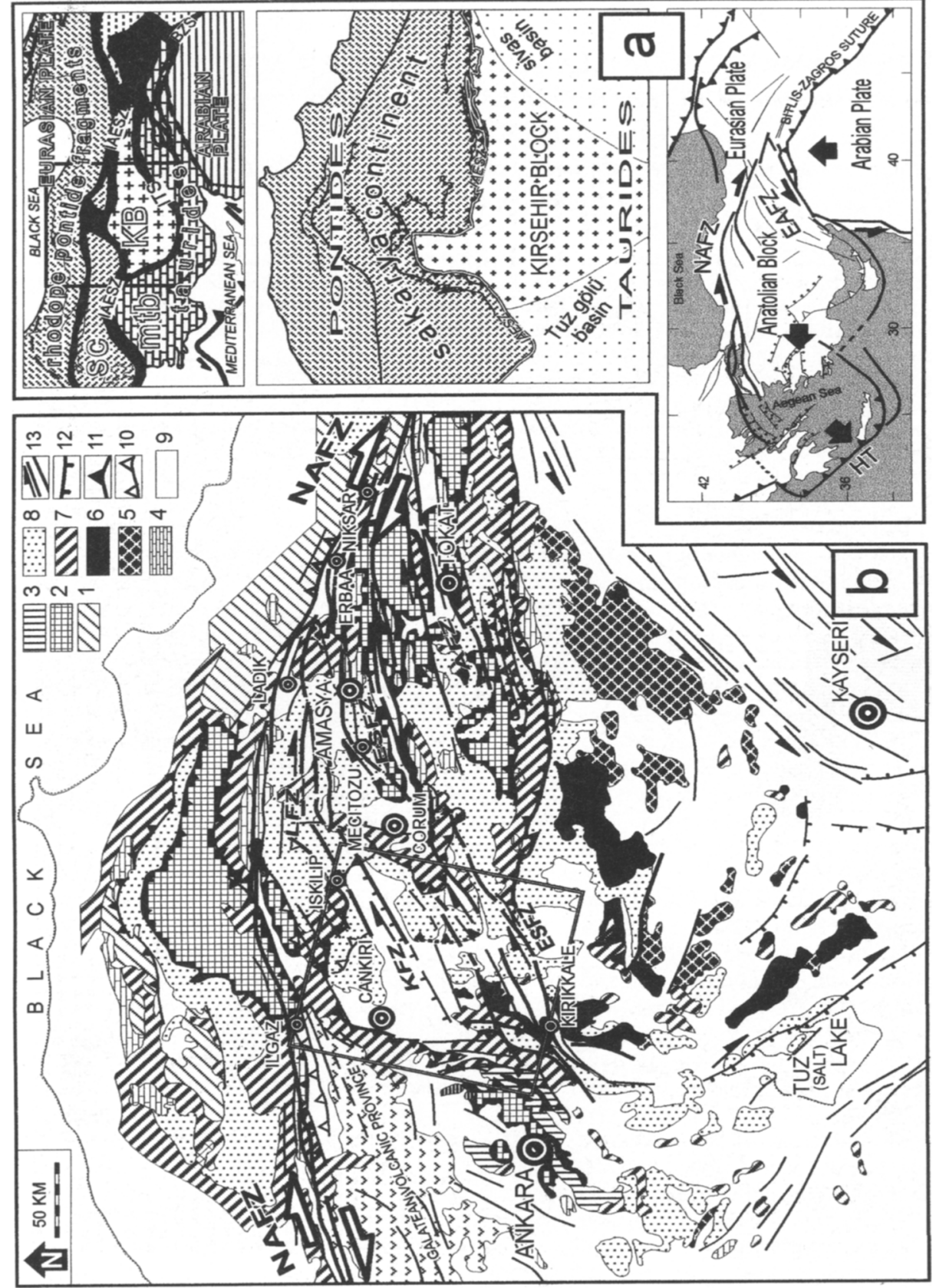

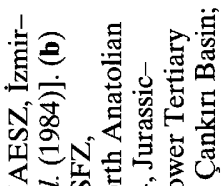
तु

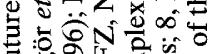

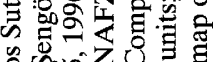

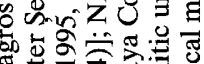
N

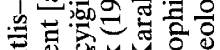
ज. 造然包 两 0 .

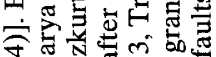

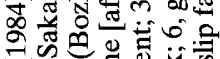
比

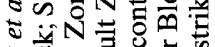
:

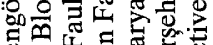
फ्.

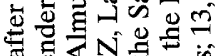

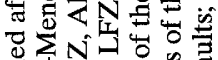

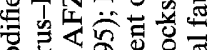
运

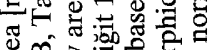

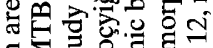

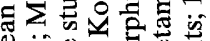

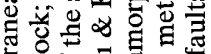

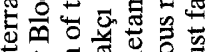

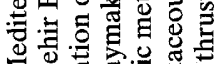

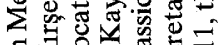
更

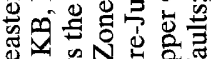

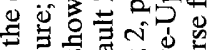

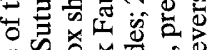

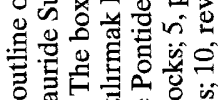

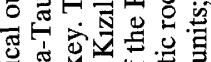
政青N

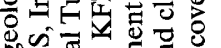

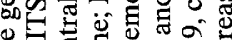
of 过 on 4 넝 응 N

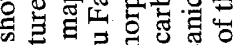

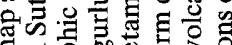
a

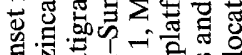

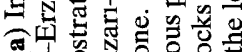
๔) 항 -

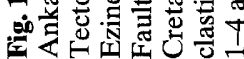




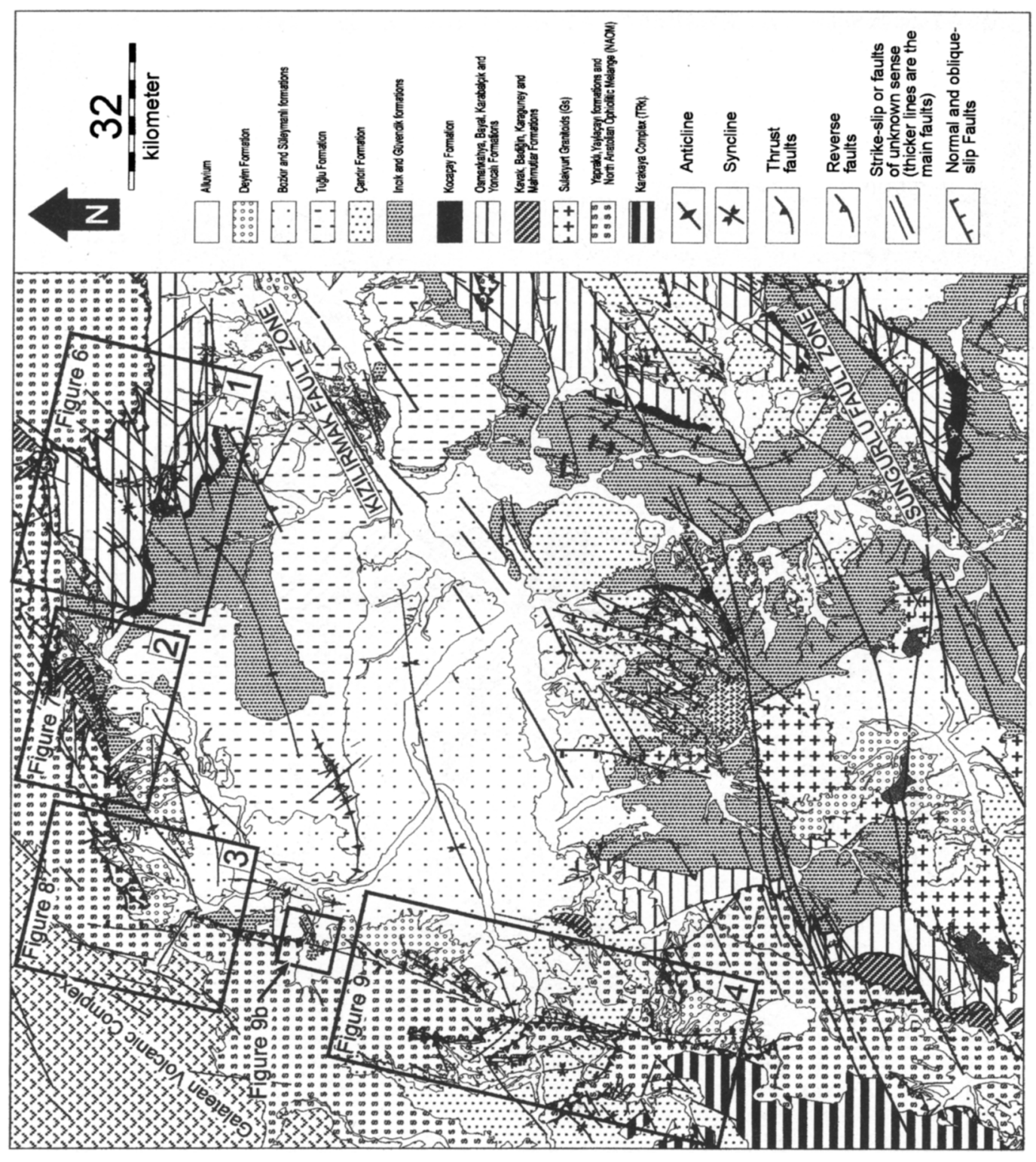


[monoclinic or triclinic symmetry of Twiss \& Unruh (1998)] can either cause local variations in the stress field or a very high deviation between the maximum resolved shear stress and the slip direction (Pollard et al. 1993). This decreases the reliability of the stress-inversion procedure and makes the identifieation of different deformation phases more difficult, but is helped if constrained by stratigraphic controls and overprinting and cross-cutting relationships (Nemcok \& Lisle 1995; Hardcastle 1989; Angelier 1994).

Fault reactivation is another source of difficulty as not all inversion procedures can cope with it. For example, Angelier's (1979, 1984) method is best suited for reactivated systems, but it has limitations because faults with pure dip-slip and strike-slip components yield unreliable results because the intermediate stress will be perpendicular to the slip direction and it will have no effect on the inversion procedure [see Angelier (1994) for the details].

Although the basic assumptions underlying stress inversion procedures have been criticized (e.g. Pollard et al. 1993; Twiss \& Unruh 1998), empirical observations and theoretical analyses (e.g. Duphin et al. 1993) show that the shear stress vectors and the slip vectors on a single isolated fault plane vary little in orientation from those predicted, i.e. the average slip remains parallel to the average shear stress, thus agreeing with the Wallace-Bott assumption (Angelier 1994). Stress inversion techniques have been applied to fault slip data from a variety of tectonic settings and have produced results that are consistent and interpretable (Pollard et al. 1993).

The aim of this study is to use the palaeostress inversion procedure to delineate the kinematic evolution of the structures within the northern part of the Çankırı Basin with respect to its structural and tectonic evolution.

\section{Background}

The Çankırı Basin (Fig. 1) is thought to be located in a zone where the Sakarya continent attached to the Pontides and the Kirșehir Block of the Taurides collided and sutured along the İmir-Ankara-Erzincan Suture Zone (İAESZ), which demarcates the former position of the northern branch of Neotethys (Şengör \& Yilmaz 1981). The timing of collision is under debate. Okay (1984) argued that it occurred at the end of the Late Cretaceous. Şengör \& Yilmaz (1981), when reviewing the plate tectonic evolution of Turkey from the Precambrian to the present, proposed a Late PalaeoceneMiddle Eocene age for the timing of the collision. Görür et al. (1984) proposed a Middle Eocene origin based on their study of the Tuzgölü (Salt Lake) Basin which is located in the western margin of the Kurșehir Block and is thought to have a similar stratigraphical and evolutionary history to the Cankırı Basin (Fig. 1). It is possible that these different dates reflect a diachronous collision which may be due to irregularities at the promontories of colliding blocks and oblique collision (Dewey 1977)

Besides being affected by collisionary process, the Çankırı Basin was subjected to further deformation in post-middle Miocene being a part of the Anatolian wedge caught between the expulsive transcurrent motions on the North and East Anatolian Faults. This has resulted a number of northwards, convex, dextral strikeslip faults which bifurcate from the North Anatolian Fault Zone (NAFZ) (Barka \& Hancock 1984; Şengör et al. 1985; Kaymakçı \& Koçyiğit 1995). The Kızılırmak and Sungurlu Fault Zones are the two major splays of the NAFZ, which partly controlled the Late Miocene evolution of the Çankırı Basin (Fig. 1c).

Fig. 2. Generalized tectonostratigraphic column of the units exposed in and around the Çankırı Basin. MN zones in the age column are obtained from Hans de Bruijn (pers. comm.). 1, North Anatolian Ophiolitic Mélange (NAOM) (ophiolitic mélange); 2, Yaylaçayı Formation (distal fore-arc sequence); 3, Yapraklı Formation (proximal forearc facies); 4, Sulakyurt Granites of the Kirşehir Block that intruded in pre-Palaeocene time; 5 , Kavak Formation (red clastics and carbonates); 6, Badiğin Formation (neritic limestones); 7, Karagüney Formation (clastics derived mainly from the Kırșehir Block) 8, Mahmatlar Formation (clastic rocks derived from the Sulakyurt Granite); 9, Dizilitaşlar and Hacıhalil Formations (mainly turbiditic clastic rocks and intercalated limestones); 10, Yoncalı Formation (Eocene flysch); 11, Karabalçık Formation (distributary channel conglomerates and sandstones with coal seams); 12, Bayat Formation (Eocene volcanic rocks and volcaniclastic rocks); 13, Osmankahya Formation (mixed-environment clastics and red beds); 14, Kocaçay Formation (Middle Eocene nummulitic limestone covering both basin infill and the Sulakyurt Granites), 15, Incik Formation (Upper Eocene-Middle Oligocene continental red clastic rocks); 16, Güvendik Formation (Middle Oligocene evaporites); 17, Kilçak Formation; 18, Altıntaş Formation (fluvial red clastics exposed only in the Hancılı Basin); 19, Hancılı Formation (lacustrine deposits exposed only in the Hancılı Basin); 20, Çandır Formation; 21, Tuğlu Formation (Lower-Upper Miocene evaporites and lacustrine shale-marl); 22; Süleymanlı Formation (fluviolacustrine red clastic rocks); 23, Bozkır Formation (evaporites); 24, Deyim Formation (fluvial clastic rocks); 25 , alluvium. 


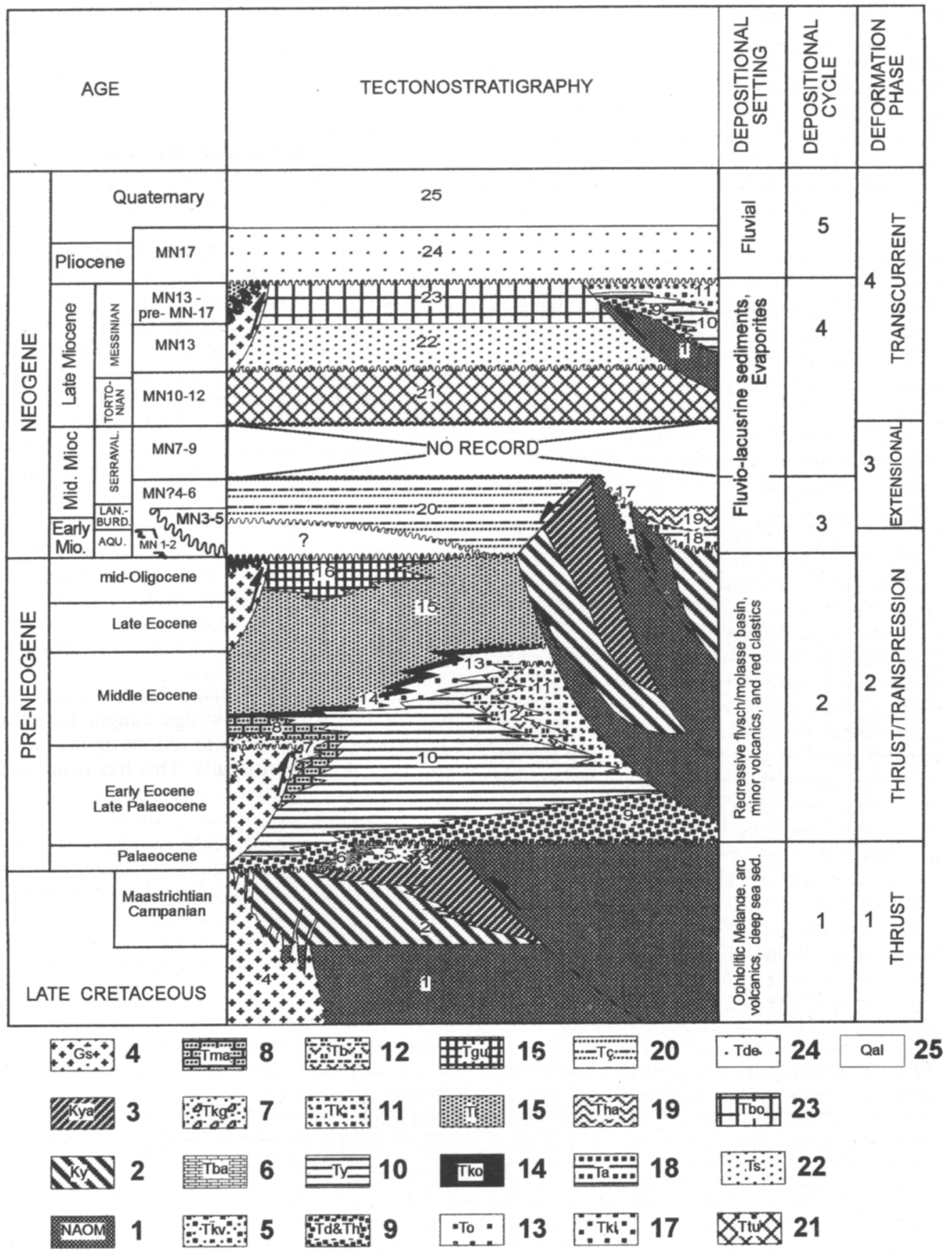




\section{Geological setting}

The Çankırı Basin has an $\Omega$-shape (Fig. 1b), with the main outcrops lying in the west, north and east. In the south it is delineated by the granitoids of the Kirşehir Block of the Taurides (Fig. 1). The rim of the Çankırı Basin is marked by an ophiolitic mélange, the North Anatolian Ophiolitic Mélange (NAOM) [terminology after Rojay $(1993,1995)]$, which is thought to underlie the sedimentary infill of the Çankırı Basin. The basement of the mélange is thought to be the Kurssehir Block in the southern part but is unknown in the north, i.e. the İAESZ may lie below the Cankırı Basin rather than skirting around its northern margin as indicated in Fig. 1.

The fill of the Cankırı Basin is $>4 \mathrm{~km}$ thick and accumulated in five different cycles of sedimentation (Fig. 2). The oldest cycle comprises Upper Cretaceous volcaniclastic rocks and regressive shallow-marine units, and Palaeocene mixed-environment red clastics and carbonates (Özçelik 1994). The subsequent cycles have been partly studied by Dellaloğlu $e t$ al. (1992) and their scheme is followed in this study. The second cycle is a Late Palaeocenemid-Oligocene regressive flysch to molasse sequence overlain by a widespread, thin $(<100 \mathrm{~m})$ nummulitic limestone of Middle Eocene age which passes up into a very thick (up to 2000 m) Upper Eocene-mid-Oligocene continental red clastic sequence intercalated by mid-Oligocene evaporites. The third cycle is represented by fluvio-lacustrine clastic rocks deposited in the Early-Middle Miocene. The fourth cycle is represented by deposits laid down under Late Miocene fluvio-lacustrine conditions and are frequently alternating with evaporites. The Plio-Quaternary alluvial fan deposits and recent alluvium locally overlie all of these units (Fig. 2). Names of the formal units are mostly adopted after Dellaloğlu et al. (1992).

The main structures shaping the current geometry of the Çankırı Basin (Fig. 1c) are the thrust faults defining its western and northern rims. The eastern margin is defined by a belt of north-northeast striking folds. In the south, the basin fill onlaps on to the Kirșehir Block. Other major structures affecting the Cankırı Basin are the dextral Kizilirmak Fault Zone, oriented southwest-northeast in the central part of the basin, and the Sungurlu Fault Zone in the southeast. Both are regarded as splays of the NAFZ. The south-central area of the basin is dominated by a number of curvilinear faults oriented approximately northeast-southwest (Fig. 1c).

\section{Methodology}

\section{Data collection}

The relative ordering of fault motions and related deformation was established from overprinting and cross-cutting relations. The age constraints were applied through careful documentation and analysis of the fault structures in each of the above stratigraphical horizons. To avoid problems due to relative block and fault plane interactions [see Pollard et al. (1993) and Twiss \& Unruh (1998)] sampling sites were as small as possible and structurally homogeneous (Hancock 1985). In addition, the displacement should also be as small as possible (a few centimetres) so that it should not accommodate significant strain (Hardcastle 1989), therefore the principal strain and stress axes should remain parallel.

Most Lower Tertiary infill of the Çankırı Basin is only exposed in the three belts forming the western, northern and eastern rims of the basin (Fig. 1). The central parts of the basin are covered mainly by evaporites that are very susceptible to gravity induced ductile deformation and were not included in the analysis. As a result, the study was limited to the northern and western margins which form a convex arcuate belt (see Fig. 1). Four subareas were selected for detailed study. Two of them lie in the northern margin of the basin. In subarea 1 (1 in Fig. 1c) the infill of the basin is well exposed and the boundary is affected by dextral northeast trending transcurrent faults (Fig. 1c). The second subarea ( 2 in Fig. 1c) is dominated by anastomosing east-northeast trending thrust faults. In addition, Upper Cretaceous-Palaeocene units are better exposed in this area than in any other part of the basin. The third subarea lies where the rim of the Çankırı Basin turns from an overall east-west trend to a north-south one ( 3 in Fig. 1c). In this subarea, the basin units are post-Middle Eocene in age. The fourth subarea (4 in Fig. 1c) covers the western margin of the basin and the Neogene Hancll Basin. In this area, mainly Upper Cretaceous units and Miocene-Recent units are exposed; the Lower Tertiary units are missing or not exposed.

In order to have structurally homogeneous data (Hancock 1985), the size of a sampling site has been restricted to $<50 \mathrm{~m}$ diameter. Areas larger than this were subdivided into subsites and analysed independently. More than 600 slickenline data from 72 sites have been collected. For each fault measured in the field, the following features were noted: (1) the attitude of the plane; (2) the stratigraphic units which 
were displaced; (3) whenever possible, the relative order of movement; (4) the amount of offset; (5) type of slickenline; (6) type of shear sense indicators; (7) evidence of ductility (i.e. breccia v. mylonite); and (8) degree of planarity. Each was given a confidence value of 1-4 (excellent to poor) [as explained in Hardcastle (1989)]. If no movement sense could be deduced, the fault was not used in the analyses, which applied to $c .20 \%$ of the data.

\section{The stress-inversion procedure and separation of movement phases}

It was found that most of the measured faults had undergone reactivation, as seen from overprinting kinematic indicators which were subsequently used to order the different phases of movement (Fig. 3). The maximum number of slickenline overprinting and/or overgrowth patterns observed in any fault plane was three, which was encountered in $10 \%$ of the faults, $c$. $25 \%$ had two overprinting sets.

The relative age of each movement phase was determined independently for each fault from a given subarea, carefully correlated with data from other subareas to form a regional subset and then processed (see Fig. 4) by Angelier's method (1989) using his computational procedures. During the analyses, the data were carefully examined and data from each site were correlated with those from other sites in a subarea such that the slip data with the same order of occurrence could be grouped together for preliminary stress-inversion processing (see flowchart in Fig. 4 for the steps followed in the stress-inversion procedure). The computational procedures used were: direct inversion (INVD); right dihedra (P- \& T-dihedra); and iterative methods (R4DT, R4DS, R2DT, R2DS).

After preliminary processing, faults giving spurious results were re-examined. If the results still remained spurious they were separated from the data set and treated separately. After removal of spurious data, the stress tensor was recomputed and reanalysed using the software developed by Hardcastle \& Hills (1991) for the automated separation of stress tensors associated with the different deformation phases as indicated from the field observations. Concordant data were then taken, so indicating that the computed stress tensor is most likely to be correct. The initial spurious data were recomputed by the Hardcastle \& Hills (1991) method and if again spurious they were deleted; if concordant they were included and reanalysed.

In order to determine the mean stress tensor
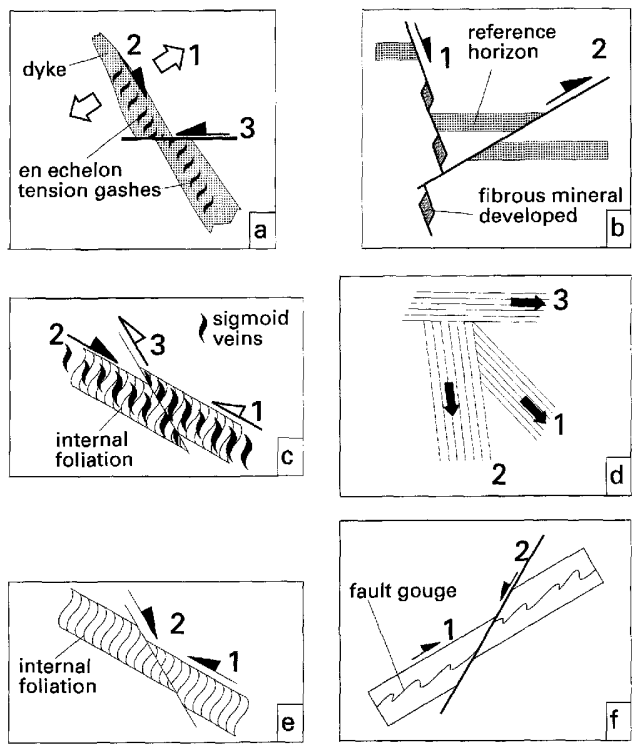

Fig. 3. Schematic illustrations of the criteria used to date relative occurrences of slip data. Numbers 1-3 indicate the sequences of deformation, oldest to youngest, respectively. (a) A dyke indicating extension (1) (large opposite arrows), then tension veins indicating dextral movement (2), all displaced sinistrally (3). (b) Hybrid joints with fibrous mineral development having normal separation (1) are displaced by reverse faults (2). (c) Internal foliation within the shear zones with reverse separation (1) sigmoidal veins indicating that an opposite sense of movement (2) developed, they are then displaced by a reverse fault with opposite movement to the veins (3). (d) Cross-cutting slickensides. (e) Shear zone with internal foliation indicating reverse separation (1) displaced by a fault with an opposite sense of movement (2). (f) Folded fault gouge with reverse separation displaced by a fault with an opposite sense of movement. The numbers are relative to each other and do not necessarily correspond to the order of the regional deformation phases.

configuration for a given movement phase in each subarea, all the data from each site and each phase were grouped and the above procedure was repeated. After the mean stress orientations were determined, all of the raw data was reprocessed using Hardcastle \& Hills' (1991) approach and the results were compared with those obtained using the direct-inversion method. As the minimum number of slickenline data required in the direct-inversion method is four (Angelier 1979), the data from sites containing fewer than this number were used only in the construction of the mean stress tensor for the subarea within which it was located. After the stress tensors for each set at each site were 


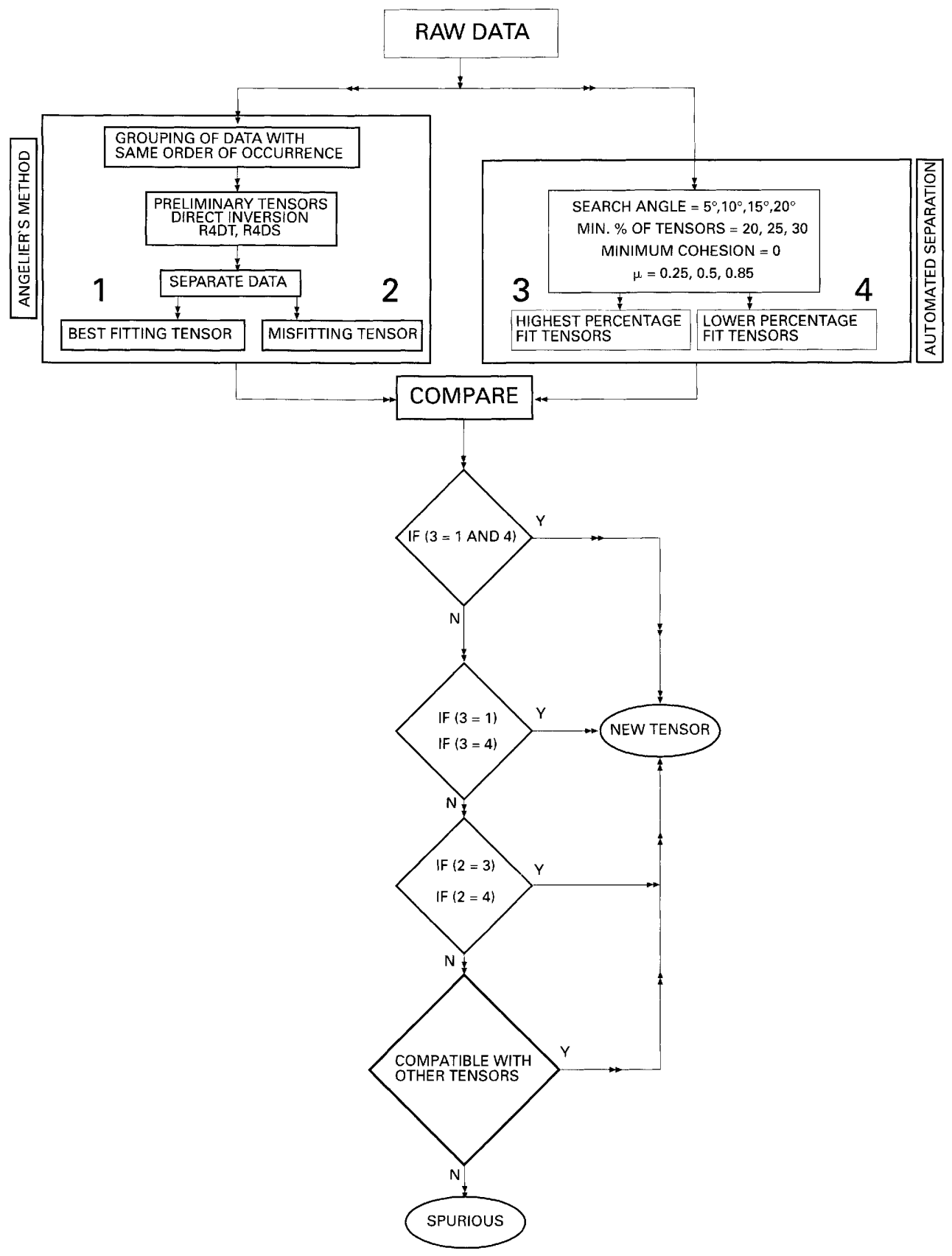

Fig. 4. A flowchart of steps followed during the analysis of the data. The data were analysed independently using two different methods which were then compared. After determination of tensors and separation of the data into best-fitting and misfitting faults, the results were compared with the automated method. If best-fitting and misfitting tensors of Angelier's method fell within the highest percentage fit tensors of the automated method, then each subset was ascribed two separate acceptable tensors. If not, and if they fell within the lower percentage fit tensor, then further analysis was carried out until reasonable and acceptable tensors were obtained (i.e. lowest misfit angles of $<15^{\circ}$ obtained for all groups. Only faults with $>45^{\circ}$ are accepted as spurious $(<2 \%$ of the whole data). This process is repeated for each class of structures (number of relative chronology) for each phase and for determining mean regional (subarea-based) stress tensor configurations. 
Table 1. Field characteristics of sites in sub area 1

\begin{tabular}{|c|c|c|c|c|c|c|c|}
\hline Site $^{\dagger}$ & Shear & Vein & $\mathrm{OP}$ & S.line & $\mathrm{CC}$ & Unit $^{\dagger}$ & No. move. \\
\hline 60 & - & - & 2 & SP & 2 & $\mathrm{~K}$ & 2 \\
\hline 61 & - & - & 2 & SP & 2 & $\mathrm{~K}$ & 2 \\
\hline 62 & - & + & 3 & $\mathrm{SP}, \mathrm{Ca}$ & 4 & $\mathrm{~K}$ & 4 \\
\hline 63 & + & + & 3 & $\mathrm{SP}, \mathrm{Ca}$ & 4 & $\mathrm{~K}$ & 4 \\
\hline 64 & + & + & 3 & $\mathrm{SP}, \mathrm{Ca}$ & 4 & $\mathrm{~K}$ & 4 \\
\hline 65 & - & - & 2 & - & 2 & $\mathrm{~Tb}$ & 2 \\
\hline 66 & + & - & - & - & - & $\mathrm{K}$ & 1 \\
\hline 77 & + & + & 2 & $\mathrm{Ca}$ & 3 & Ty & 3 \\
\hline 78 & + & - & 2 & - & - & To & 2 \\
\hline 79 & - & + & 2 & - & 2 & Tko & 2 \\
\hline 80 & - & + & 2 & $\mathrm{Ca}$ & 2 & To & 2 \\
\hline 81 & - & + & 2 & $\mathrm{Ca}$ & 2 & $\mathrm{Ti}$ & 2 \\
\hline 82 & - & & 2 & - & 2 & To & 2 \\
\hline 115 & - & + & 2 & $\mathrm{Ca}$ & 2 & $\mathrm{Ti}$ & 2 \\
\hline 116 & - & + & 2 & $\mathrm{Ca}$ & 2 & $\mathrm{Ti}$ & 2 \\
\hline 117 & - & + & 2 & $\mathrm{Ca}$ & 2 & $\mathrm{Ti}$ & 2 \\
\hline 118 & - & + & - & - & - & $\mathrm{Ti}$ & 1 \\
\hline 119 & - & + & 2 & $\mathrm{Ca}$ & 2 & $\mathrm{Ti}$ & 3 \\
\hline
\end{tabular}

OP, Number of overprinting slickenline sets; s.line, fibrous slickensides associated with the sampled faults (SP, serpentine; $\mathrm{Ca}$, calcite); $\mathrm{CC}$, number of cross-cutting relationships either with veins, shear zones or other faults; no. move., number of movement sets encountered in each site (the numbers do not necessarily correspond to the order of the regional deformation phases). ${ }^{*}+$, exists; -, not observed. ${ }^{\dagger} \mathbf{K}$, Upper Cretaceous units (NAOM; Ky; Kya); Ty, Yoncalı Formation; To, Osmankahya Formation; Tko, Kocaçay Formation; Ti, İncik Formation.

determined, they were correlated with other sites. By combining the stratigraphic information and relative order of different sets, the stress tensors were arranged into ordered deformation phases.

In both the direct-inversion and the Hardcastle \& Hills' (1991) methods, $15^{\circ}$ was chosen as the maximum angular deviation acceptable for the computation of a given stress tensor. Faults with greater angular deviations were considered as spurious and deleted.

The tensors computed for a subarea should be more reliable than site-based tensors. The reasons for this are obvious but include deviations due to a particular site being located at the termination of a fault or in an area where two or more structures interact. Both will cause a deviation of the local stress tensor from the regional tensor (Pollard et al. 1993) and will tend to cancel out in the regional compilation (Angelier 1994).

\section{Results for subarea 1}

The location of subarea 1 is shown in Fig. 1c. The main structures in this area are the eastnortheast trending thrust faults (TF1) along which the Upper Cretaceous NAOM was thrust over the Yaylaçayı Formation which, in turn, was thrust onto the Late Palaeocene-
Middle Eocene Yoncalı and Karabalçık Formations (Fig. 5a). Relatively, the oldest slickensides which record the first movement on TF1 include pitches with dominant thrust fault character $\left(>45^{\circ}\right)$ with a dextral lateral component. This thrust belt is displaced dextrally by a number of later north-east-southwest oriented strike-slip faults that cut through both the hanging-wall and footwall blocks. Further to the southwest, the Yoncali Formation was thrust over the Incik Formation and the Middle Eocene units - the Karabalçı, Bayat, Osmankahya and Kocaçay Formations - along fault TF3 (Fig. 5a). A number of synsedimentary unconformities were observed in the İncik Formation during the field studies (especially near sites $81-82$ and 115 in Fig. 5a), implying that TF2 (Fig. 5a) operated during the deposition of the Incik Formation in Late Eocene-pre-midOligocene times. The main fault planes of TF2 and TF3 are dominated by overprinting slickensides. Relatively, the oldest of these slickensides have pitches ranging between 15 and $35^{\circ}$ with a sinistral sense of movement. Likewise, the younger slickensides have pitches dipping at $<20^{\circ}$ with a dextral sense of movement. These relations indicate that TF2 and TF3 were developed as transpressional sinistral strike-slip faults and later reactivated into dextral strike-slip faults. 


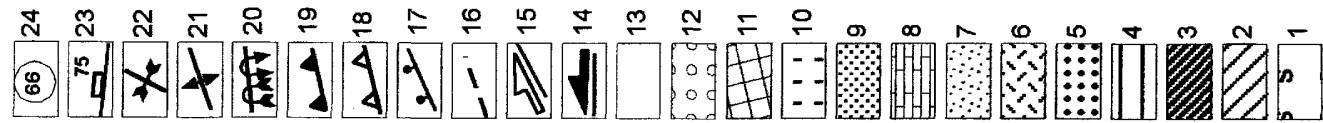

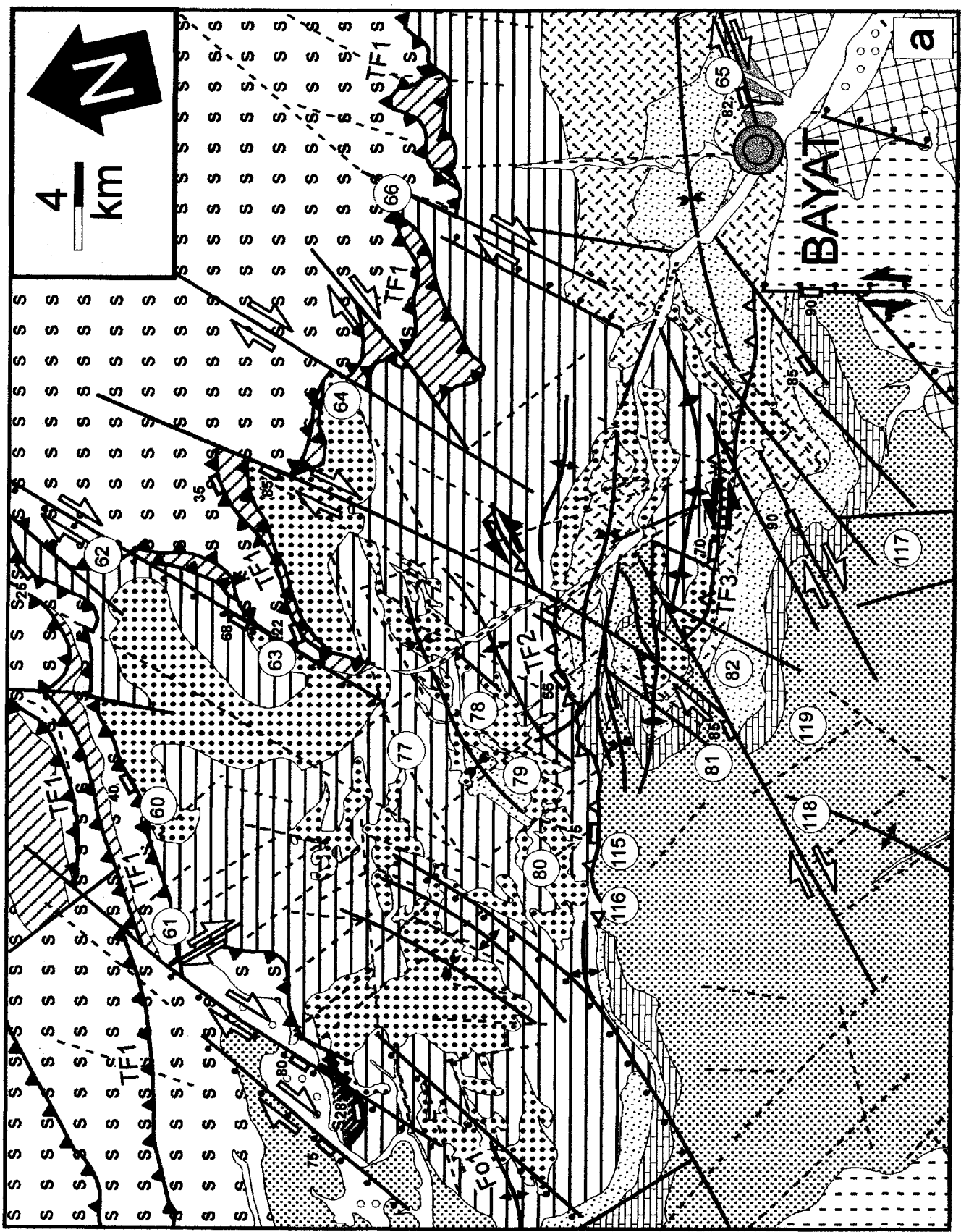



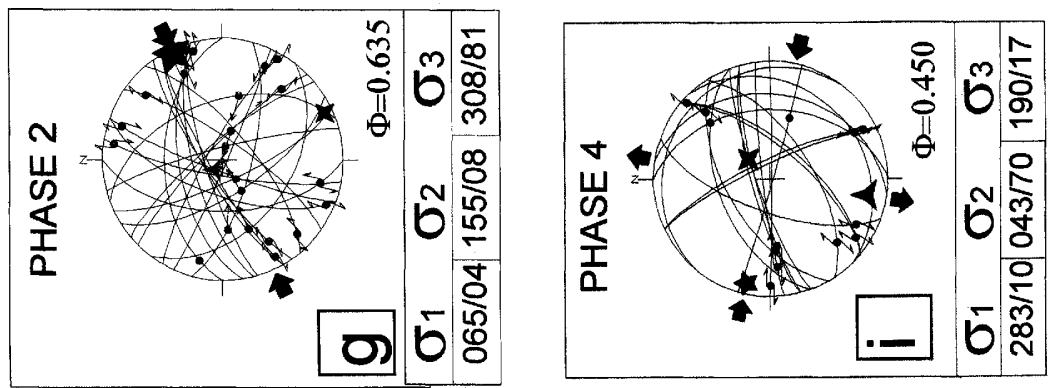

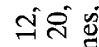

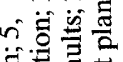
ฮี 急宓声

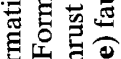
药

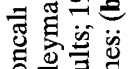

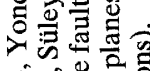

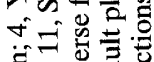
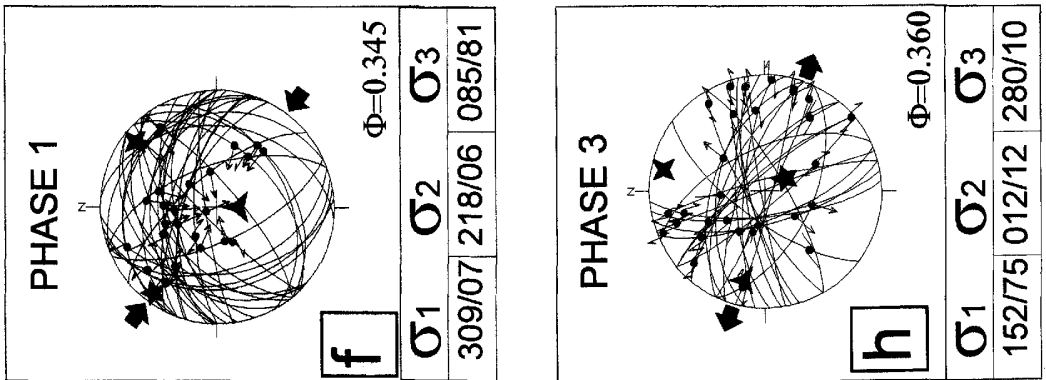

응

可. 定国

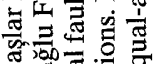
可呵产 武气 लं日 产造造

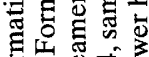
동 更家 * ó

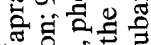
궁. 氜 도웡

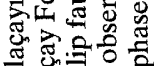

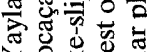
궁 $\therefore \infty$ क्ष
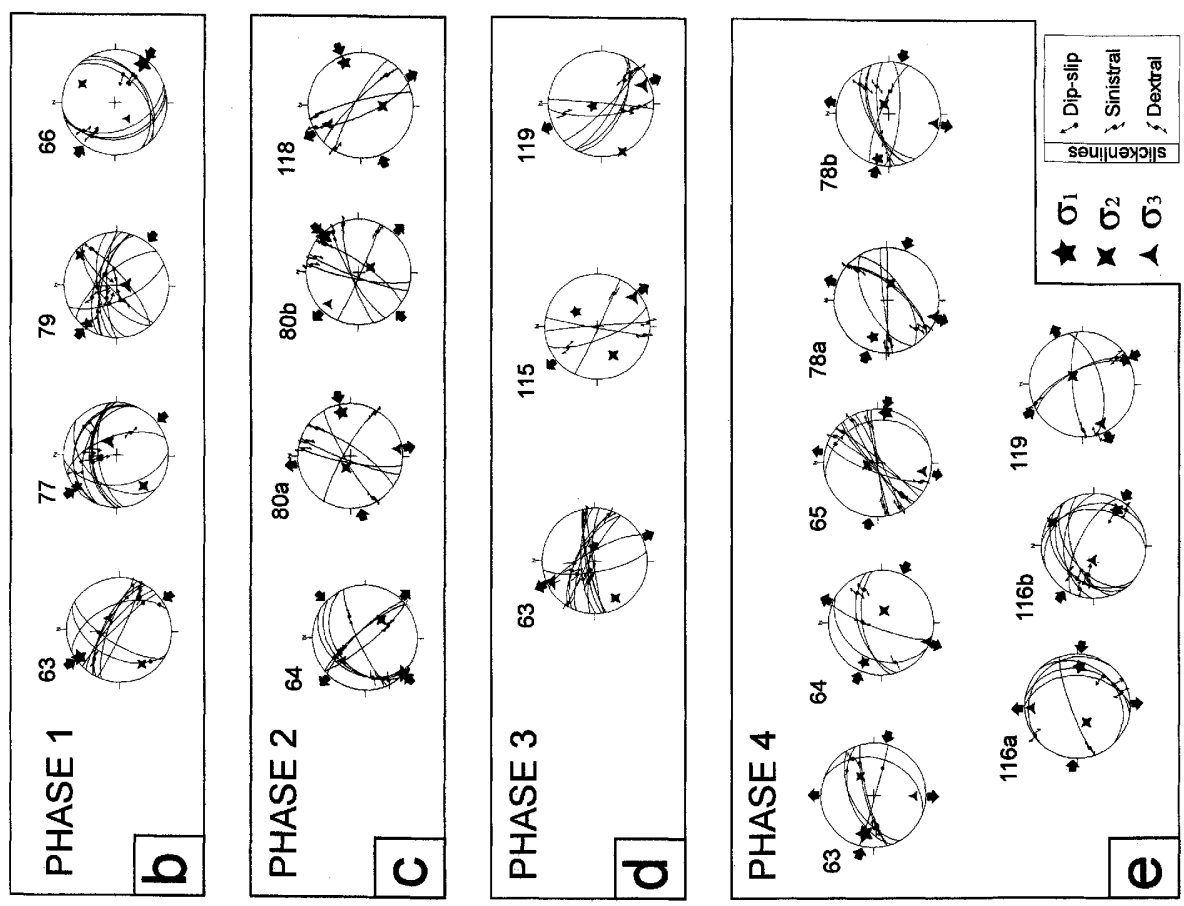

这画要

乙

퉁 웡

我的产

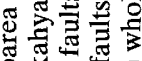

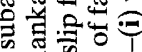

目

a 0 :

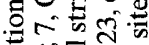

ฮี 을 붑

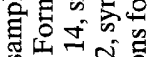
क

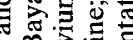
包。寻 สี 的 응 을

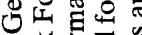
美 的青

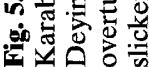



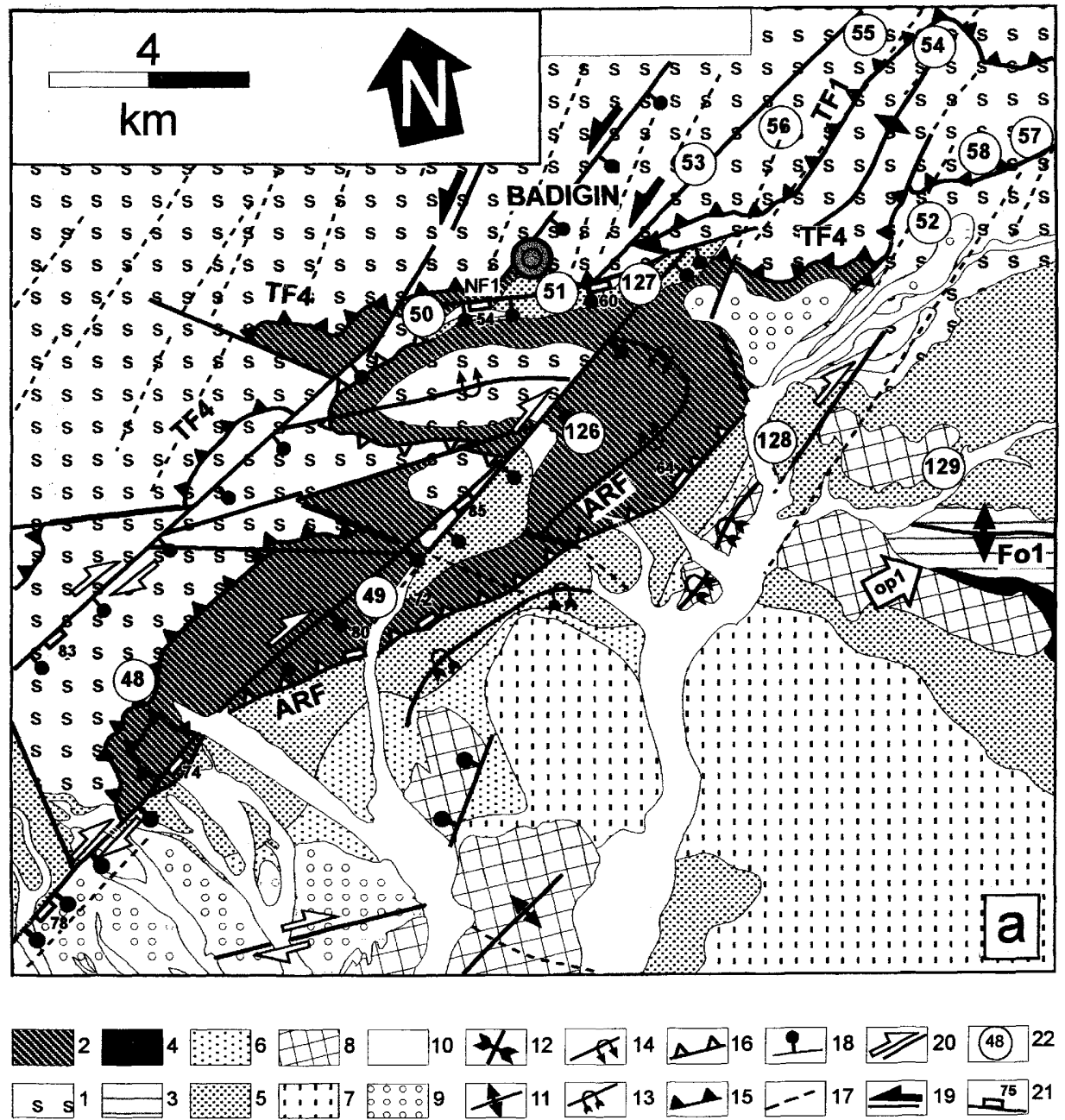

Fig. 6. (a) Geological map and sample locations in subarea 2. 1, NAOM; 2, Yapraklı, Kavak and Bağdiğin Formations; 3, Incik Formation; 4, Çandır Formation; 5, Tuğlu Formation; 6, Süleymanlı Formation; 7, Deyim Formation; 8, alluvium; 9 , anticline; 10 , syncline; 11, overturned syncline; 12 , overturned anticline; 13 , thrust faults; 14 , reverse faults; 15 , photo-lineaments; 16 , normal faults; 17 , sinistral strike-slip faults; 18 , dextral strikeslip faults; 19 , dips of faults where they are best observed in the field; 20, sample site locations. Plots of fault planes: (b)-(e) fault planes, slickenlines and stress orientations for each site (f)-(i) whole data in a particular phase and subarea (lower hemisphere equal-area projections). 

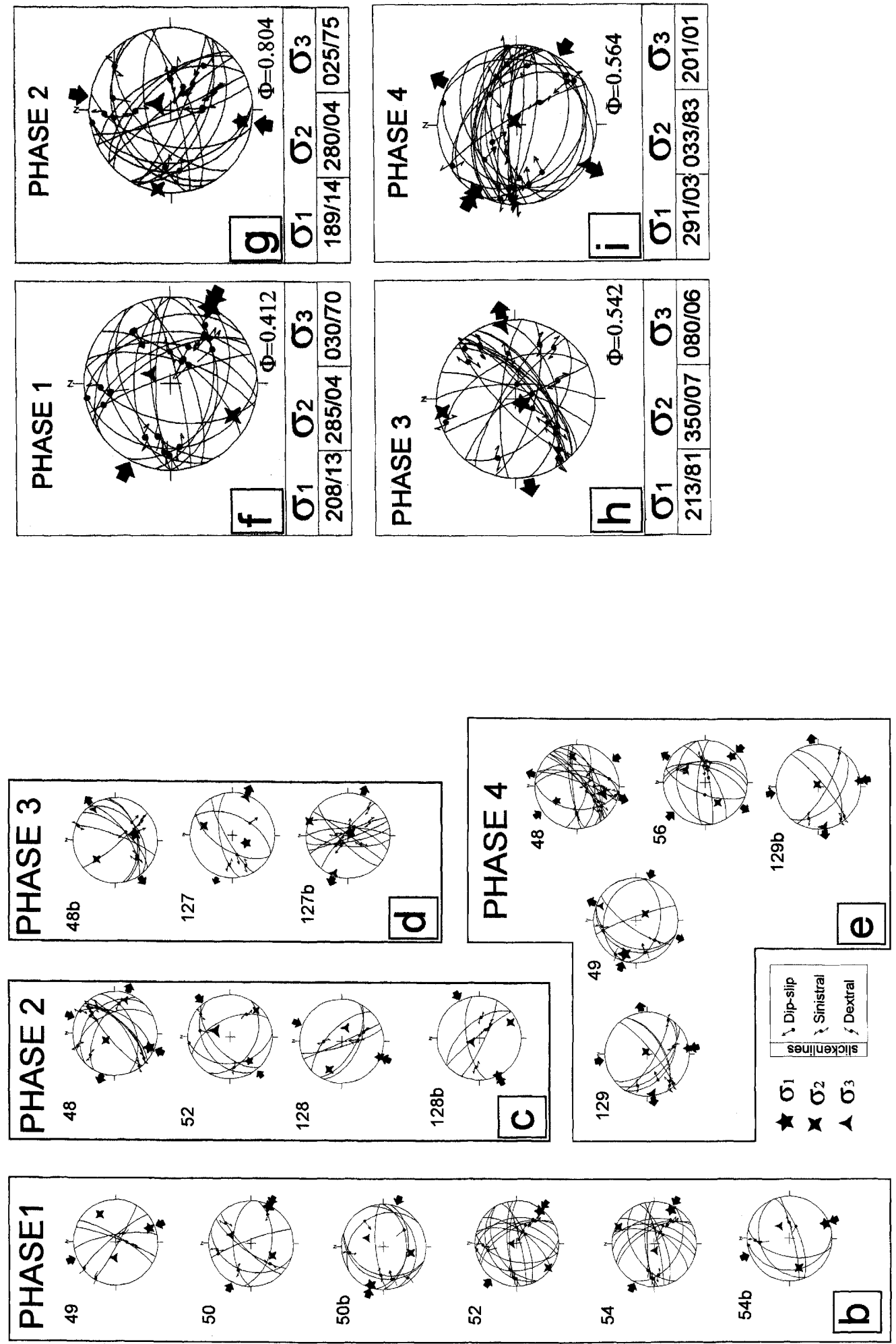


\section{Palaeostress inversion}

Eight sites were selected (see Table 1) and, from the field analyses, four phases of fault activity were recognized using the criteria outlined in Fig. 3. In some of the sites (62-64) the sampled faults have three sets of overprinting slickenlines. These faults, in turn, cross-cut other structures such as shear zones, én-echelon veins and other sets of faults (as indicated in Fig. 3). A combination of all of these relationships led to the identification of four sets of fault movements. Based on their relative timing, the sets of faults having similar movements were directly assigned to the deformation phases arranged from older to younger (Nemcok \& Lisle 1995). These sites were used as a reference in the analysis of other sites that have fewer sets of fault movements.

From the 18 sites sampled, 12 sites have sufficient slip data for the construction of sitebased palaeostress tensors (Fig. 5b-e). From these sites, 19 palaeostress configurations have been constructed. The data from the remaining eight sites were combined in constructing the mean stress tensor for the whole subarea (see Fig. 5f-i).

Phase 1. Only four sites had sufficient data for construction of a site-based stress tensor (Fig. $5 b)$. The average orientations of the principal stresses and the stress ratio for the subarea are: $\sigma_{1}=309^{\circ} \mathrm{N} / 07^{\circ}, \sigma_{2}=218^{\circ} \mathrm{N} / 06^{\circ}, \sigma_{3}=085^{\circ} \mathrm{N} / 81^{\circ}$; and $\Phi=0.345$ (Fig. 5f). The major stress direction is north-northwest-south-southeast and the minor stress direction $\left(\sigma_{3}\right)$ is subvertical, indicating thrust tectonics in this phase. The orientation of $\sigma_{1}$ is approximately perpendicular to the main northeast-southwest striking segments of TF1 and oblique to the other segments (Fig. 5a).

Phase 2. The second phase was recognized in four sites (Fig. 5c), which also give comparable results. One site, $64 \mathrm{~b}$, gives a slight deviation; this site is very close to the intersection of TF1 and a northeast-southwest trending oblique-slip fault. The deviation may be due to interaction of these faults [as explained by Pollard et al. (1993)]. In the subarea, both $\sigma_{1}$ and $\sigma_{2}$ are subhorizontal, and $\sigma_{3}$ is subvertical in all sites and the subarea-based tensor indicates thrusting during this deformation phase. The orientation of subarea-based principal stresses and the stress ratio are: $\sigma_{1}=065^{\circ} \mathrm{N} / 04^{\circ}, \sigma_{2}=155^{\circ} \mathrm{N} / 08^{\circ}$, $\sigma_{3}=308^{\circ} \mathrm{N} / 81^{\circ}$; and $\Phi=0.635$ (Fig. $5 \mathrm{~g}$ ). The orientation of $\sigma_{1}$ is almost perpendicular to the northwest-southeast striking segments of TF1 and TF3, and the northwest striking folds east of the TF2 fault.

Phase 3. Three sites had sufficient slip data for the construction of site-based stress tensors. The orientations of the principal stresses are relatively consistent in each site (Fig. 5d). The horizontal components of $\sigma_{3}$ are oriented north-northeast-southwest. The orientation of subarea-based average stress tensors and the stress ratio are: $\sigma_{1}=152^{\circ} \mathrm{N} / 75^{\circ}, \sigma_{2}=012^{\circ} \mathrm{N} / 12^{\circ}$, $\sigma_{3}=280^{\circ} \mathrm{N} / 10^{\circ}$; and $\Phi=0.360$ (Fig. $5 \mathrm{~h}$ ), indicating extensional deformation in this phase.

Phase 4. This phase is recognized in seven sites (Fig. 5e). Except for site 119, all other sites yielded compatible results. The horizontal component of $\sigma_{1}$ is oriented approximately westnorthwest-east-southeast, which is also parallel to the subarea-based stress tensor. The orientations of subarea-based principal stresses and the stress ratio are: $\sigma_{1}=283^{\circ} \mathrm{N} / 10^{\circ}, \sigma_{2}=043^{\circ} \mathrm{N} / 70^{\circ}$, $\sigma_{3}=190^{\circ} \mathrm{N} / 17^{\circ}$; and $\Phi=0.450$ (Fig. 5i), indicating strike-slip deformation in this phase.

\section{Results for subarea 2}

The location of this subarea is shown in Fig. 1c. This area is also dominated by northeast trending thrust faults. Upper Cretaceous units are thrust over the Palaeocene units by TF1 near Badiğin and TF4 to the east (Fig. 6a). Relatively, the oldest slickenlines observed on TF4 indicate a dominant thrust fault character with dextral lateral component. The Palaeocene units (Kavak and Badiğin Formations; see Fig. 2) are thrust over the Upper Eocene-Middle Oligocene İncik Formation along the Ayseki Reverse Fault (ARF). In the central parts of the subarea, the Palaeocene units, the İncik Formation and the Upper Miocene units are folded and overturned parallel to the ARF (Figs $1 \mathrm{c}$ and $6 \mathrm{a}$ ).

In the southeastern part of the study area, an east-west trending fold (Fo1), observed within Eocene-Oligocene units ( $\mathrm{Ty}$ and $\mathrm{Ti}$ ), is unconformably overlain by the relatively undisturbed Upper Miocene units (op1 in Fig. 6a).

Near Badiğin village, TF1 and TF4 are displaced by an east-west trending normal fault, NF1, which is, in turn, displaced by northeastsouthwest trending faults with an apparent sinistral offset and normal component. These faults also displace Upper Miocene units (Süleymanlı and Bozkır Formations) and the Plio-Quaternary Deyim Formation (Fig. 6a), which proves their post-Late Miocene activity. 
Table 2. Field characteristics of sites in subarea 2.

\begin{tabular}{|c|c|c|c|c|c|c|c|}
\hline Site & Shear & Vein & $\mathrm{OP}$ & S.line & $\mathrm{CC}$ & Unit* & No. move. \\
\hline 48 & + & + & 2 & $\mathrm{SP}, \mathrm{Ca}$ & 4 & $\mathrm{~K}$ & 4 \\
\hline 49 & - & + & 2 & $\mathrm{SP}, \mathrm{Ca}$ & 2 & $\mathrm{~K}$ & 3 \\
\hline 50 & + & + & 2 & SP & 4 & $\mathrm{~K}$ & 4 \\
\hline 51 & + & - & 3 & $\mathrm{SP}, \mathrm{Tl}$ & 3 & $\mathrm{~K}$ & 4 \\
\hline 52 & + & + & 2 & SP & 2 & $\mathrm{~K}$ & 3 \\
\hline 53 & - & + & - & $\mathrm{Ca}$ & 2 & $\mathrm{~K}$ & 2 \\
\hline 54 & - & - & 3 & $\mathrm{Ca}$ & 3 & $\mathrm{~K}$ & 3 \\
\hline 55 & - & - & 2 & $\mathrm{Ca}$ & 2 & $\mathrm{~K}$ & 2 \\
\hline 56 & - & - & - & - & - & $\mathrm{K}$ & 1 \\
\hline 57 & - & + & - & $\mathrm{Ca}$ & 2 & $\mathrm{~K}$ & 2 \\
\hline 58 & - & - & - & - & - & $\mathrm{K}$ & 1 \\
\hline 126 & - & - & - & - & - & $\mathrm{Ti}+\mathrm{Tkv}$ & 1 \\
\hline 127 & - & + & 2 & $\mathrm{Ca}$ & 2 & $\mathrm{Ti}+\mathrm{Tkv}$ & 2 \\
\hline 128 & - & - & 2 & $\mathrm{Ca}$ & 2 & $\mathrm{Ti}$ & 2 \\
\hline 129 & - & + & 2 & $\mathrm{Ca}$ & 2 & $\mathrm{Ti}$ & 2 \\
\hline
\end{tabular}

* Tkv, Kavak Formation. Other abbreviations as in Table 1.

\section{Palaeostress inversion}

Four deformation phases were recognised in this subarea. The same criteria were used for ordering the deformation phases as described in Fig. 4. The details of sites located in this subarea are given in Table 2 and results are illustrated in Fig. 6b-e.

Phase 1. Six sites had sufficient data to construct site-based stress tensors for this subarea. Although the angular discrepancy between the orientations of $\sigma_{1}$ constructed for each site and averaged for the subarea is $c .45^{\circ}$, there is a great discrepancy between the orientations of $\sigma_{2}$ and $\sigma_{3}$. The orientations of the $\sigma_{1}$ vary from northnorthwest-south-southeast to west-northwesteast-southeast and are subhorizontal in each site. $\sigma_{2}$ and $\sigma_{3}$ are oblique, although $\sigma_{3}$ is more vertical than $\sigma_{2}$ (Fig. 6b). Orientation of the stresses and the stress ratio for the subarea are: $\sigma_{1}=208^{\circ} \mathrm{N} / 13^{\circ}, \sigma_{2}=285^{\circ} \mathrm{N} / 04, \sigma_{3}=030^{\circ} \mathrm{N} / 70^{\circ}$; and $\Phi=0.412$ (Fig. 6f). Having $\sigma_{3}$ subvertical and the other stresses subhorizontal indicates thrusting in this phase.

Phase 2. Only four sites had sufficient data for construction of the site-based stress tensors. The orientation of site- and subarea-based tensors is relatively compatible. Orientation of $\sigma_{1}$ ranges from north-northwest-south-southeast to northeast-southwest (Fig. 6c). The mean subareabased principal stress orientations and the stress ratio are: $\sigma_{1}=189^{\circ} \mathrm{N} / 14^{\circ}, \sigma_{2}=280^{\circ} \mathrm{N} / 04^{\circ}$, $\sigma_{3}=025^{\circ} \mathrm{N} / 75^{\circ}$; and $\Phi=0.804$ and indicates compressive deformation. The orientation of $\sigma_{1}$ is perpendicular to Fo1 (Fig. $6 \mathrm{~g}$ ).

Phase 3. Only three sites had sufficient slip data for construction of the site-based tensors (Fig. 6d). In sites 127 and $48, \sigma_{2}$ is oblique, implying local transtension which is not observed in the subarea-based stress tensor. Only site 48 is compatible with the subarea-based tensor; others deviate from it. This relation may indicate local stress perturbations, e.g. site 127 is very close to the normal fault NF1. The orientation of the mean subarea-based principal stresses and the stress ratio are: $\sigma_{1}=213^{\circ} \mathrm{N} / 81^{\circ}$, $\sigma_{2}=350^{\circ} \mathrm{N} / 07^{\circ}, \sigma_{3}=080^{\circ} \mathrm{N} / 06^{\circ}$; and $\Phi=0.542$ (Fig. 6h). Having $\sigma_{1}$ subvertical and other stresses subhorizontal indicates extensional deformation in this phase.

Phase 4. Five sites had sufficient slip data for the construction of site-based stress tensors (Fig. $6 \mathrm{e})$. In almost all the sites, $\sigma_{2}$ is subvertical and $\sigma_{1}$ ranges from northwest-southeast to northnorthwest-south-southeast; this relation indicates strike-slip deformation. The orientation of the subarea-based mean stresses and the stress ratio are: $\sigma_{1}=291^{\circ} \mathrm{N} / 03^{\circ}, \sigma_{2}=033^{\circ} \mathrm{N} / 83^{\circ}$, $\sigma_{3}=201^{\circ} \mathrm{N} 01^{\circ}$; and $\Phi=0.564$ (Fig. 6i). Having $\sigma_{2}$ vertical and the other stresses horizontal indicates regional strike-slip deformation in this phase. Most of the thrust and reverse faults and folds trending northeast-southwest are almost perpendicular to $\sigma_{1}$. In addition, the folds within the Upper Miocene units (near site 128) are perpendicular to $\sigma_{1}$. 

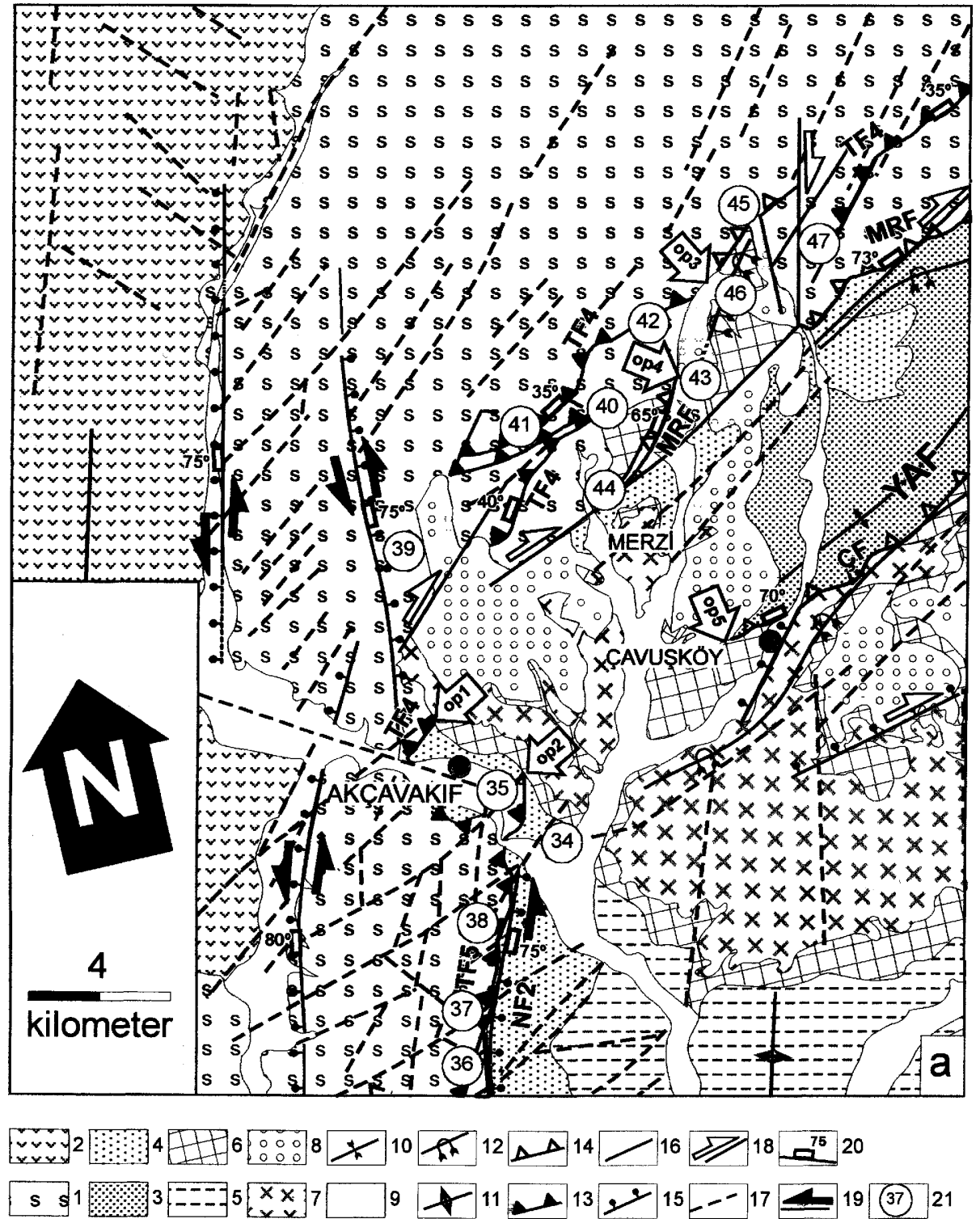

Fig. 7. (a) Geological map and sample location of subarea 3. 1, NAOM; 2, Galatean Volcanic Province [see Tankut et al. (1995) and Toprak et al. (1996)]; 3, Incik Formation; 4, Çandır Formation; 5, Tuğlu Formation; 6, Süleymanlı Formation; 7, Bozkır Formation; 8, Deyim Formation; 9, alluvium; 10, syncline; 11, anticline; 12, overturned syncline; 13 , thrust faults; 14 , reverse faults; 15 , normal faults; 16 , strike-slip faults or faults with an unknown sense of movement; 17 , photo-lineaments; 18 , dextral strike-slip faults; 19 , sinistral strike-slip faults; 20 , dips of faults where they are best observed in the field; 21 , sample site locations. Plots of fault planes: (b)-(e) fault planes, slickenlines and stress orientations for each site; (f)-(i) whole data in a particular phase and subarea (lower hemisphere equal area projections). 

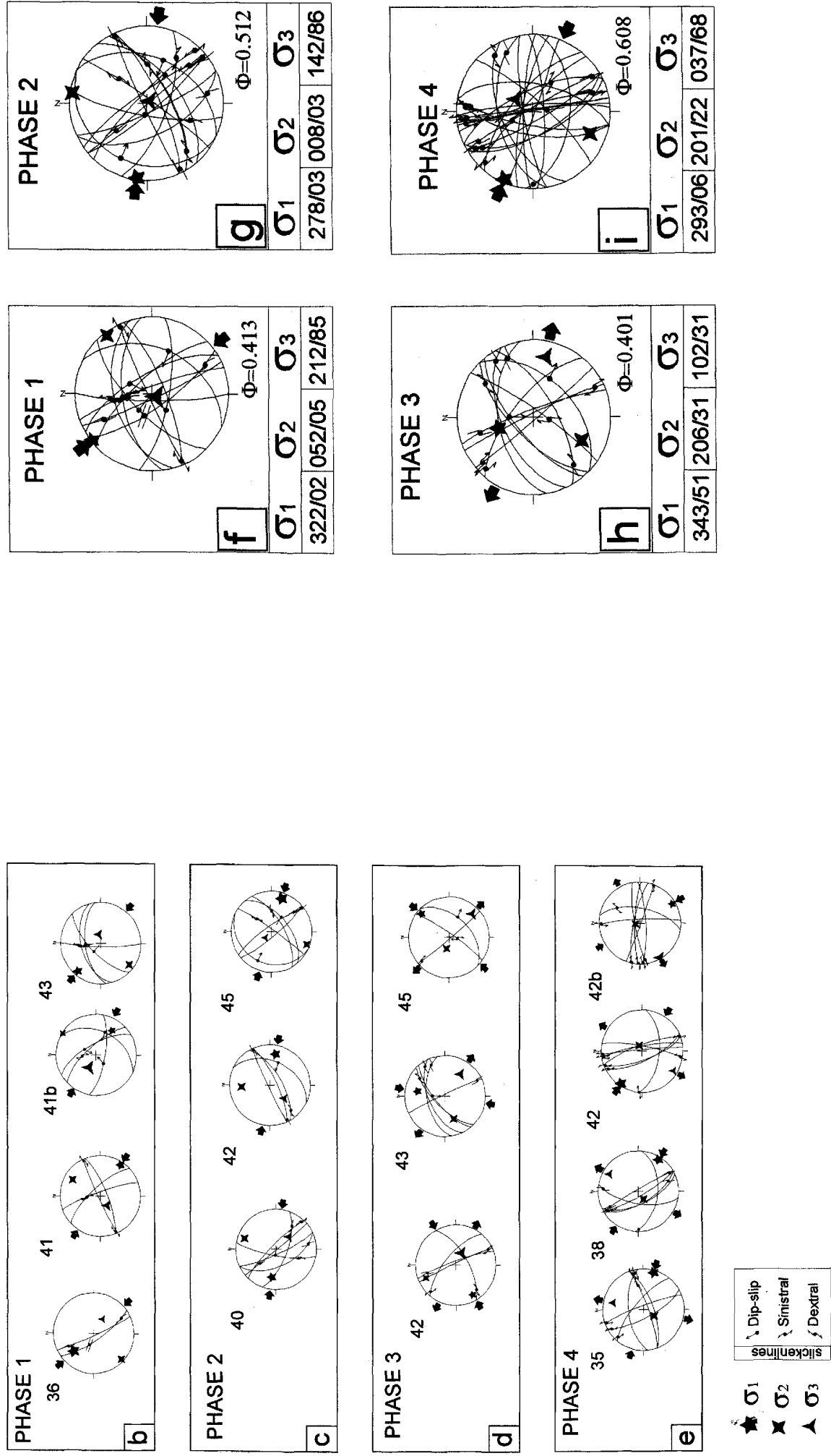

ธै ธี

606
$\times 1$ 
Table 3. Field characteristics of sites in subarea 3

\begin{tabular}{|c|c|c|c|c|c|c|c|}
\hline Site & Shear & Vein & OP & S.line & $\mathrm{CC}$ & Unit* & No. move. \\
\hline 34 & - & + & 2 & $\mathrm{Ca}$ & 2 & $\mathrm{Ti}$ & 3 \\
\hline 35 & + & + & 2 & $\mathrm{SP}, \mathrm{Ca}$ & 2 & $\mathrm{~K}$ & 2 \\
\hline 36 & - & - & 2 & SP & 2 & $\mathrm{~K}$ & 2 \\
\hline 38 & - & - & 2 & - & 2 & K & 2 \\
\hline 39 & + & - & - & SP & 2 & $\mathrm{~K}$ & 2 \\
\hline 40 & + & - & 2 & SP & 2 & $\mathrm{~K}$ & 2 \\
\hline 41 & - & - & 2 & SP & 2 & $\mathbf{K}$ & 2 \\
\hline 42 & + & + & 2 & $\mathrm{Ca}$ & 2 & $\mathrm{~K}$ & 3 \\
\hline 43 & + & + & 3 & $\mathrm{SP}, \mathrm{Ca}$ & 3 & $\mathrm{~K}$ & 4 \\
\hline 44 & - & - & - & $\mathrm{Ca}$ & - & $\mathrm{K}$ & 1 \\
\hline 45 & + & + & - & $\mathrm{SP}, \mathrm{Ca}$ & 2 & $\mathrm{~K}$ & 2 \\
\hline 46 & - & - & - & - & - & $\mathrm{K}, \mathrm{Tç}$ & 1 \\
\hline 47 & + & + & 2 & SP & 4 & $\mathrm{~K}, \mathrm{Tç}$ & 4 \\
\hline
\end{tabular}

* Tç, Çandır Formation. Other abbreviations as in Table 1.

\section{Results for subarea 3}

This area is located at the northwest corner of the Çankırı Basin (3 in Fig. 1) where the NAOM and the thrust faults bounding the western margin of the basin change their strike from north-northeast-south-southwest to northeastsouthwest. The area in which the sharpest change occurs is hidden below the Plio-Quaternary units (the Deyim Formation) (Figs 1 and $7 \mathrm{a})$. The thrust faults along which the ophiolites and Upper Cretaceous units thrust over the Middle Miocene Çandır Formation are covered by the Upper Miocene Süleymanlı and Bozkır Formations (op1 and op2 in Fig. 7a). This relation indicates that thrust activity along TF4 and TF5 took place after the Middle Miocene and prior to the Late Miocene. Along the Merzi Reverse Fault (MRF), the NAOM is thrust over the Upper Miocene Süleymanlı Formation (op3 in Fig. 7a) and the thrust contact is covered by the Plio-Quaternary Deyim Formation (op3 and 4 in Fig. 7a). TF5 is displaced by NF2, indicating that two distinct tectonic regimes gave rise to the development of these structures. The first one is thrusting that resulted in the development of TF5 and the second one is an extensional one which gave rise to NF2, which is a normal fault with a strike-slip component (Fig. 7a).

In the central-eastern part of the subarea, near Çavuşköy, the post-Middle Eocene İncik Formation was thrust over the Upper MiocenePliocene(?) Bozkır Formation along the Çavușköy Reverse Fault (ÇF) and the reverse fault contact is covered by the Plio-Quaternary Deyim Formation (op5 in Fig. 7a), indicating post-Late Miocene-Pliocene(?) formation of the reverse fault. The Deyim Formation, in turn, is displaced by northeast-southwest trending dextral strike-slip faults (Fig. 7a).

\section{Palaeostress inversion}

In this subarea, like the previous sites, four phases of fault movement are observed. These movements are assigned to deformation phases and they are ordered according to their occurrence as explained previously (see Fig. 3 ). The details of each site are given in Table 3 and the results are presented in Fig. 7b-e.

Phase 1. Only four of the 14 sites had sufficient data for the construction of site-based stress tensors (Fig. 7b). The orientations of the principal stresses are consistent on a site basis and they are also consistent with the constructed regional stress tensor (Fig. 8b). The orientation of the principal stresses and the stress ratio are: $\sigma_{1}=322^{\circ} \mathrm{N} / 02^{\circ}, \sigma_{2}=052^{\circ} \mathrm{N} / 05^{\circ}, \sigma_{3}=212^{\circ} \mathrm{N} / 85^{\circ}$; and $\Phi=0.413$ (Fig. 7f) and indicate a compressive deformation. The orientation of $\sigma_{1}$ is almost perpendicular to the trace of TF4 and oblique to the trace of TF5 and NF2.

Phase 2. Only three sites had sufficient slip data for the construction of site-based stress tensors (Fig. 7c). The orientation of principal stresses are consistent with each other on a site basis and, when averaged for all subareas, the orientation of the principal stresses and the stress ratio are: $\sigma_{1}=278^{\circ} \mathrm{N} 03^{\circ}, \sigma_{2}=008^{\circ} \mathrm{N} / 03^{\circ}, \sigma_{3}=$ $142^{\circ} \mathrm{N} / 86^{\circ}$; and $\Phi=0.512$ (Fig. $7 \mathrm{~g}$ ) and indicate a compressive deformation. $\sigma_{1}$ is almost perpendicular to TF5 and NF2, and oblique to MRF, TF4 and ÇF. 
Phase 3. Only three sites had sufficient data for the construction of the site-based stress tensors, although the horizontal component of $\sigma_{3}$ is consistent for individual sites and with the constructed mean subarea stress tensor (Fig. $7 \mathrm{~d}$ ). Orientation of regional stresses and the stress ratio are: $\sigma_{1}=343^{\circ} \mathrm{N} / 51^{\circ}, \sigma_{2}=206^{\circ} \mathrm{N} / 31^{\circ}$, $\sigma_{3}=102^{\circ} \mathrm{N} / 31^{\circ}$; and $\Phi=0.401$ (Fig. $7 \mathrm{~h}$ ). None of the principal stresses are oriented vertically or horizontally and there are stress permutations (Angelier 1994) between the sites. This relation may indicate the state of so-called 'tri-axial strain conditions' (Reches 1978a,b). The orientation of the horizontal component of $\sigma_{3}$ is almost perpendicular to NF2 and other major normal faults with a sinistral strike-slip component (Fig. 7a).

Phase 4. Four sites had sufficient slip data for the construction of site-based stress tensors (Fig. $7 \mathrm{e}$ ). The orientations of site-based tensors are relatively consistent with each other. In each site, $\sigma_{2}$ is subvertical and the horizontal component of $\sigma_{1}$ ranges from west-northwest-east-southeast to northwest-southeast. The orientations of subarea-based mean stresses and the stress ratio are: $\sigma_{1}=293^{\circ} \mathrm{N} / 06^{\circ}, \sigma_{2}=201^{\circ} \mathrm{N} / 22^{\circ}, \sigma_{3}=037^{\circ} \mathrm{N} /$ $68^{\circ}$; and $\Phi=0.608$ (Fig. 7i) and indicate a compressive deformation. The horizontal component of $\sigma_{1}$ is almost perpendicular to TF5, NF2 and MRF, and oblique to TF4 and ÇF.

\section{Results for subarea 4}

This subarea includes the western margin of the Çankırı Basin and extends into the adjacent Hancll Basin, which is separated from the Çankırı Basin by TF5 and NF2 (Figs 1c and 8a). Along TF5, the Upper Cretaceous units are thrust over the Middle Miocene Çandır Formation and the fault contacts are covered by Upper Miocene units in the north outside subarea 4 (op1-3 in Fig. 8b). Along TF6, Upper Cretaceous rocks are thrust over the Middle Miocene Hancill Formation. Along TF7 and TF8, the Upper Cretaceous rocks are thrust over the Lower-Middle Miocene Aslantaș and Hancll Formations; these units are locally overturned along TF8. TF7 is covered by the PlioQuaternary Deyim Formation, indicating prePlio-Quaternary activity of the fault. Along TF9, the Lower-Middle Miocene Aslantaş and Hancll Formations are thrust over Upper Cretaceous rocks. TF10 is a set of thrust faults developed within the Upper Cretaceous and Palaeocene rocks. It is covered by the PlioQuaternary Deyim Formation, indicating prePlio-Quaternary activity of this fault set.
TF5 is displaced by a number of approximately north-northeast-south-southwest striking oblique-slip faults with normal components (e.g. NF3) that strike almost parallel to TF5. TF6-TF9 are displaced by a number of approximately northeast-southwest striking strike-slip faults, some of which have a normal component of movement (Fig. 8a).

In the Çankırı Basin, the folds are oriented in two directions. The folds developed in the Çandır Formation are oriented north-south to north-northeast-south-southwest and the ones developed in the Upper Miocene units are oriented northeast-southwest. This relation indicates two phases of folding. The earlier folding postdates the deposition of the Middle Miocene Çandır Formation and predates the Upper Miocene units, and the latter postdates the deposition of Upper Miocene rocks.

The folds in the Hancll Basin are oriented in two different directions. One set is oriented northwest-southeast, parallel to the thrust faults TF6-TF9. This relation indicates thrustrelated folding of the units in the Hancll Basin after deposition of Hancil Formation in the Early Middle Miocene. The second set is oriented northeast-southwest, parallel to the folds in the Çankırı Basin affecting the Upper Miocene units (Süleymanlı and Bozkır Formations).

\section{Palaeostress inversion}

Twenty-one sites were selected for the construction of site-based stress tensors. As in the previous subareas, four phases of fault movements were again recognized. These movements are assigned into deformation phases and are ordered according to their occurrence as explained previously (see Fig. 4). The details of each site are given in Table 4 and the results are presented in Fig. 8c-f.

Phase 1. Seven sites had sufficient slip data for the construction of site-based stress tensors. Except for site 136 (Fig. 8c), the orientation of the principal stresses are consistent on a site basis and in all other sites; $\sigma_{3}$ is subvertical, $\sigma_{1}$ is oriented in a northwest-north-northwest to southeast-south-southeast direction and $\sigma_{2}$ is subhorizontal. The orientation of the mean regional principal stresses and the stress ratio are: $\sigma_{1}=165^{\circ} \mathrm{N} / 01^{\circ}, \sigma_{2}=255^{\circ} \mathrm{N} / 16^{\circ}, \sigma_{3}=071^{\circ} \mathrm{N} /$ $74^{\circ}$; and $\Phi=0.372$ (Fig. $8 \mathrm{~g}$ ), indicating that thrusting occurred during this phase.

Phase 2. Only four sites had sufficient slip data for the construction of site-based stress tensors 

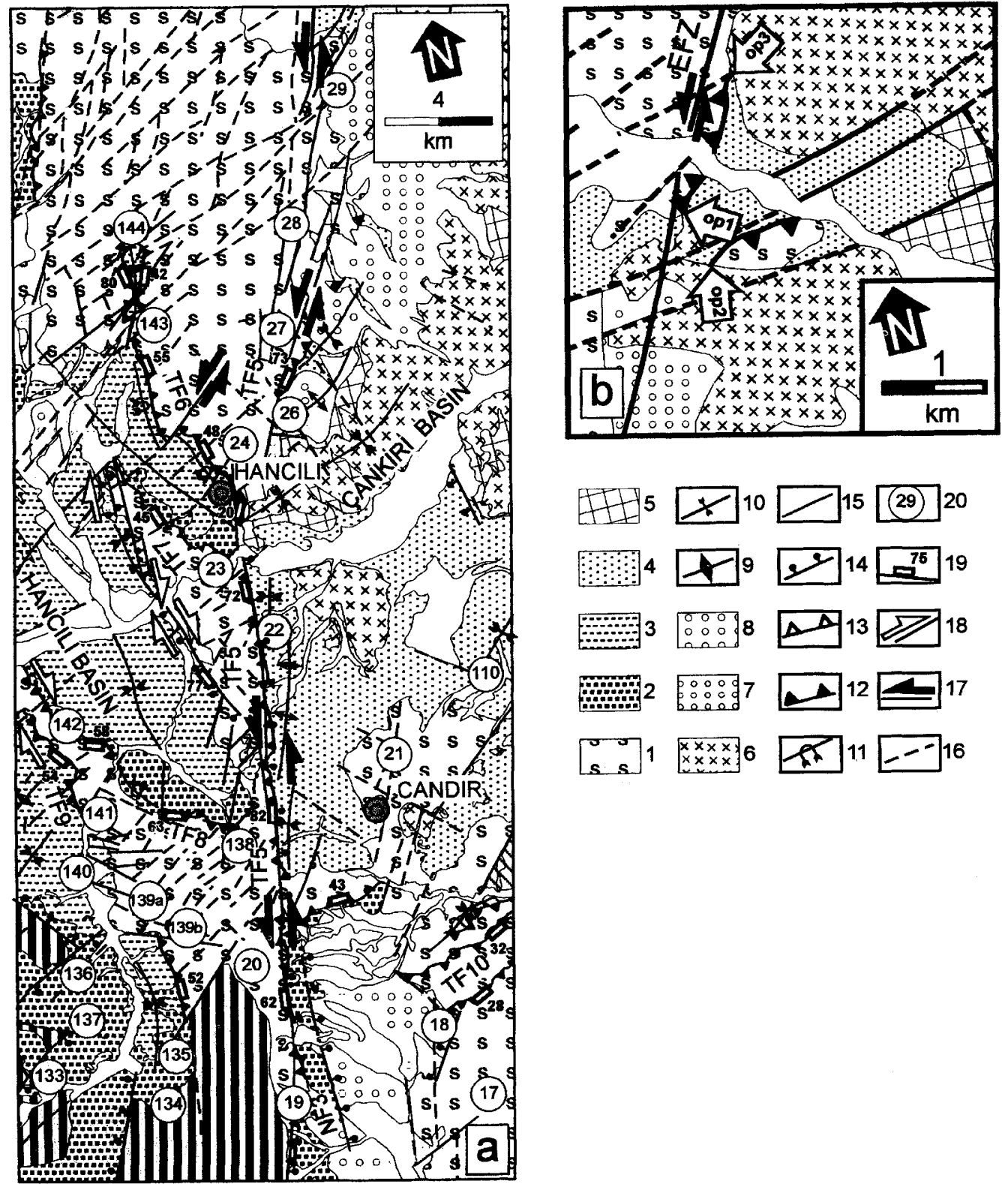

Fig. 8. (a) Geological map and sample location of subarea 4. 1, NAOM; 2, Aslantaş and Kılçak Formations; 3, Hancılı Formation; 4, Çandır Formation; 5, Süleymanlı Formation; 6, Bozkır Formation; 7, Deyim Formation; 8, alluvium; 9 , anticline; 10 , syncline; 11 , overturned syncline; 12 , thrust faults; 13 , reverse faults; 14 , normal faults; 15 , strike-slip faults or faults with an unknown sense of movement; 16 , photo-lineaments; 17 , sinistral strike-slip faults; 18 , dextral strike-slip faults; 19 , dips of faults where they are best observed in the field; 20 , sample site locations. (b) Map showing the relationship between thrusting of the NAOM onto the Çandir Formation and covering of the fault contact by the Bozkir Formation (see Fig. 1c for the location of the map). Plots of fault planes: (c)-(f) fault planes, slickenlines and stress orientations for each site; (g)-(j) whole data in a particular phase and subarea (lower hemisphere equal-area projections). 

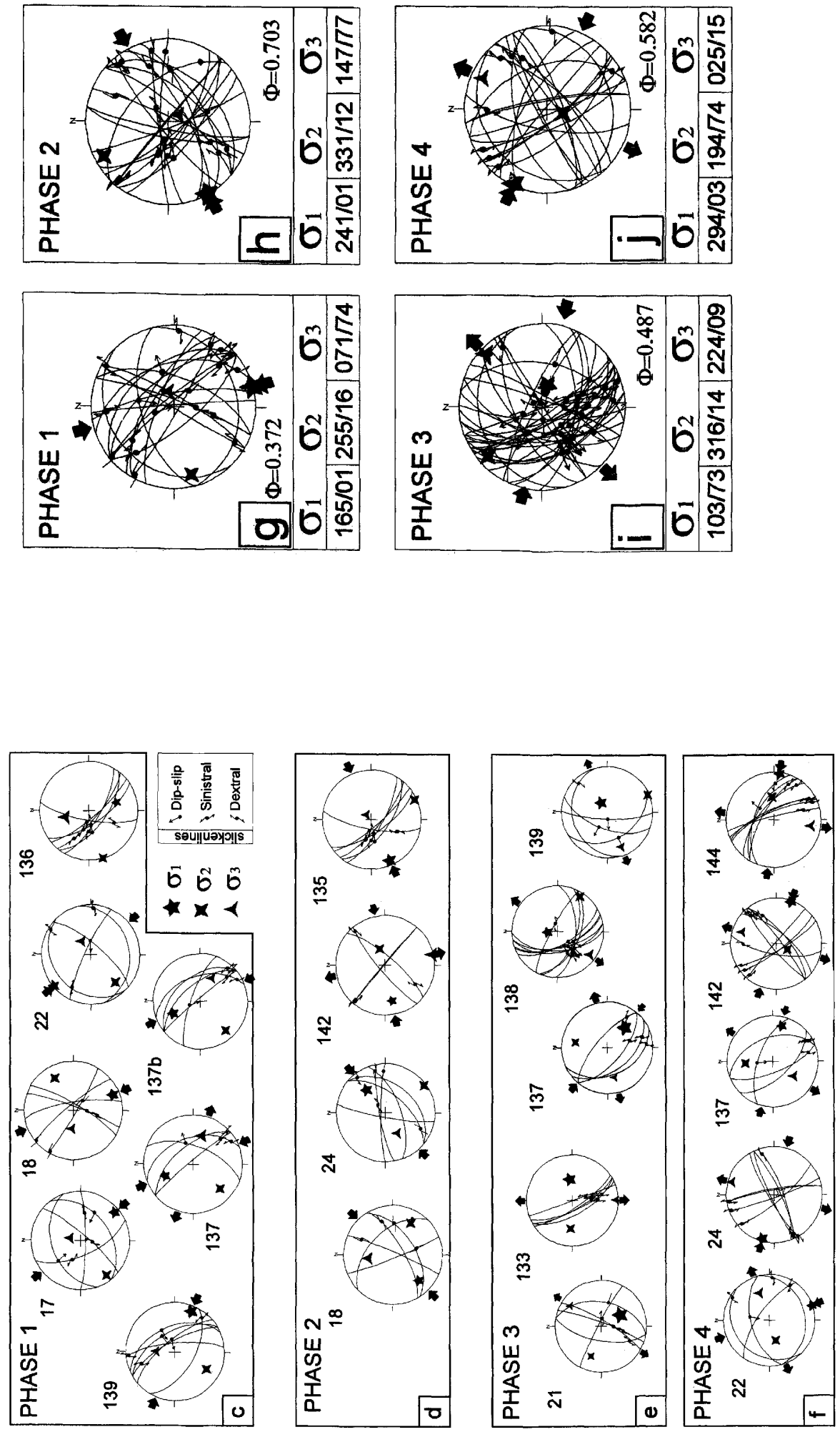
Table 4. Field characteristics of sites in subarea 4.

\begin{tabular}{|c|c|c|c|c|c|c|c|}
\hline Site & Shear & Vein & OP & S.line & $\mathrm{CC}$ & Unit* & No. move. \\
\hline 17 & - & - & 2 & - & 2 & $\mathrm{Ti}$ & 2 \\
\hline 18 & + & + & - & $\mathrm{Ca}$ & 2 & $\mathrm{~K}$ & 3 \\
\hline 19 & + & + & - & $\mathrm{SP}, \mathrm{Ca}$ & 3 & $\mathrm{~K}$ & 3 \\
\hline 20 & - & + & - & - & - & $\mathrm{K}$ & 2 \\
\hline 21 & + & - & 2 & - & 2 & $\mathrm{~K}$ & 3 \\
\hline 22 & + & + & 2 & $\mathrm{Ca}$ & 2 & $\mathrm{~K}$ & 3 \\
\hline 23 & - & - & - & - & - & $\mathrm{K}$ & 1 \\
\hline 24 & + & + & 2 & - & 3 & $\mathrm{~K}$ & 4 \\
\hline 25 & - & - & - & - & - & - & - \\
\hline 26 & + & - & - & - & 2 & $\mathbf{K}$ & 2 \\
\hline 27 & - & - & - & - & - & $\mathbf{K}$ & 1 \\
\hline 28 & - & - & - & - & - & $\mathrm{K}$ & 1 \\
\hline 29 & - & - & - & - & - & $\mathrm{K}$ & 1 \\
\hline 133 & - & - & - & - & - & $\mathrm{Ta}$ & 1 \\
\hline 134 & - & + & - & $\mathrm{Ca}$ & - & Tha & 1 \\
\hline 135 & - & + & - & $\mathrm{Ca}$ & 2 & Tha & 2 \\
\hline 136 & - & + & - & $\mathrm{Ca}$ & 2 & Tha & 2 \\
\hline 137 & + & & 2 & - & 2 & TRK, Ta & 3 \\
\hline 138 & + & + & 2 & - & 2 & $\mathrm{~K}, \mathrm{Tha}$ & 3 \\
\hline $139 a$ & + & + & 2 & - & 2 & $\mathrm{~K}$ & 3 \\
\hline $139 b$ & + & + & 2 & $\mathrm{SP}, \mathrm{Ca}$ & 2 & $\mathrm{~K}, \mathrm{Ta}$ & 3 \\
\hline 140 & - & - & - & - & - & $\mathrm{Ta}$ & 1 \\
\hline 141 & + & - & - & - & 2 & Tha & 2 \\
\hline 142 & + & - & - & - & 2 & Tha & 2 \\
\hline 143 & - & - & - & - & - & Tha & 1 \\
\hline 144 & - & - & 2 & $\mathrm{Ca}$ & 2 & Tha & 2 \\
\hline
\end{tabular}

* Ta, Aslantaş Formation; Tha, Hancılı formation. Other abbreviations as in Table 1.

(Fig. 8d). The orientation of $\sigma_{2}$ and $\sigma_{3}$ is variable in each site, whilst $\sigma_{1}$ is relatively consistent and oriented east-northeast-west-southwest to northeast-southwest. The orientation of the averaged subarea-based stresses and the stress ratio are: $\sigma_{1}=241^{\circ} \mathrm{N} / 41^{\circ}, \sigma_{2}=331^{\circ} \mathrm{N} / 12^{\circ}, \sigma_{3}=$ $147^{\circ} \mathrm{N} / 77^{\circ}$; and $\Phi=0.703$ (Fig. $8 \mathrm{~h}$ ), indicating thrusting during this phase.

Phase 3. Six sites had sufficient slip data for the construction of site-based stress tensors (Fig. $8 \mathrm{e})$. In all the sites, $\sigma_{1}$ is subvertical and other stresses are subhorizontal. The horizontal component of $\sigma_{3}$ is relatively consistent in each site, but other stresses are variable in orientation. This may be because the magnitudes of the $\sigma_{2}$ and $\sigma_{3}$ are very close to each other, resulting in stress permutations (Angelier 1994). In addition, the orientation of the horizontal component of $\sigma_{3}$ is approximately perpendicular to the thrust faults (TF6-TF9) in the Hancili Basin whence most of the data came. The orientation of the mean regional principal stresses and the stress ratio are: $\sigma_{1}=130^{\circ} \mathrm{N} / 73^{\circ}$, $\sigma_{2}=316^{\circ} \mathrm{N} / 14^{\circ}, \sigma_{3}=224^{\circ} \mathrm{N} / 09^{\circ} ;$ and $\Phi=0.487$ (Fig. 8i). Having $\sigma_{1}$ subvertical and other stresses subhorizontal indicates extensional deformation in this phase.

Phase 4. Five sites had sufficient slip data for the construction of site-based stress tensors (Fig. $8 f)$. The orientation of the principal stresses are variable, whilst $\sigma_{1}$ is relatively consistent in each site except for site 22 . It is oriented westnorthwest-east-southeast, while the horizontal component of $\sigma_{3}$ is oriented north-northeastsouth-southwest. The orientation of mean subarea-based stresses and the stress ratio are: $\sigma_{1}=$ $294^{\circ} \mathrm{N} / 03^{\circ}, \sigma_{2}=194^{\circ} \mathrm{N} / 74^{\circ}, \sigma_{3}=025^{\circ} \mathrm{N} / 25$; and $\Phi$ $=0.582$ (Fig. 8j), indicating strike-slip deformation in this phase.

\section{Discussion}

The results obtained are summarized in Fig. 9, in which both the site and subarea stress tensors are presented. They are important to the structuring of the Çankırı Basin subarea stress tensors and the discussion will concentrate on them. 


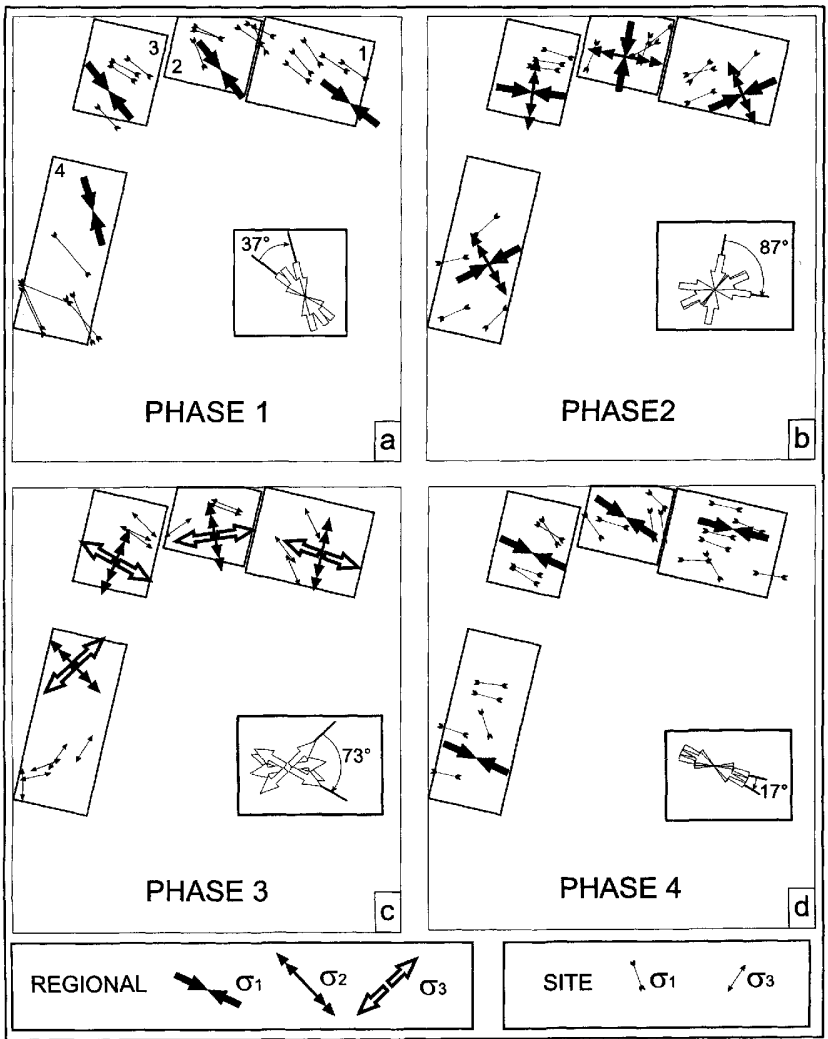

Fig. 9. Plots of horizontal components of $\sigma_{1}[(\mathbf{a}),(\mathbf{b})$ and $(\mathbf{d})], \sigma_{2}[(\mathbf{b})$ and $(\mathbf{c})]$ and $\sigma_{3}(\mathbf{c})$ in different phases and subareas $(1-4)$.

\section{Phase 1}

As stated above, Phase 1 is characterized by compressional deformation in which the orientation of $\sigma_{1}$ is subhorizontal and that of $\sigma_{3}$ is subvertical. When the results are considered it can be seen that $\sigma_{1}$ has a consistent northwest trend in the northern and northwestern margins but a north-northwest trend in the western margin; this gives an overall discrepancy of $37^{\circ}$ (Fig. 9a). The orientation of $\sigma_{1}$ in the north (subareas 1-3) is almost perpendicular to the main thrust faults and oblique to the ones in the western margin of the basin (Fig. 10). The youngest units affected in this phase are preLate Palaeocene; therefore, this deformational phase operated until pre-Late Palaeocene time.

\section{Phase 2}

This phase is also characterized by compressional deformation in which $\sigma_{1}$ is subhorizontal and $\sigma_{3}$ is subvertical, although some sites do indicate local strike-slip deformation in which $\sigma_{1}$ and $\sigma_{3}$ are both subhorizontal and $\sigma_{2}$ is subvertical. The averaged trend of $\sigma_{1}$ is very variable, changing from northeast-southwest in subareas 1 and 2 to almost north-south in subarea 2, to east-west in subarea 3 (Fig. 10b); the angular discrepancy between the subareas is $87^{\circ}$ (Fig. 9b). The fault slip data ascribed to this phase are observed only in the pre-Burdigalian units, therefore, a Middle Eocene-preBurdigalian age is ascribed to this phase.

\section{Phase 3}

This phase is characterized by extensional deformation in which $\sigma_{1}$ is subvertical and $\sigma_{3}$ is subhorizontal. The orientation of $\sigma_{3}$ changes from west-northwest in subareas 1 and 3, to east-northeast in subarea 2 and northeast trend in subarea 4 (Fig. 9c); this gives an overall angular discrepancy of $73^{\circ}$ (Fig. 9c). The orientation of the horizontal component of $\sigma_{3}$ in each subarea is oblique to the faults, which were previously supposed to be active in this deformation phase (Fig. 10c). The fault slip data 


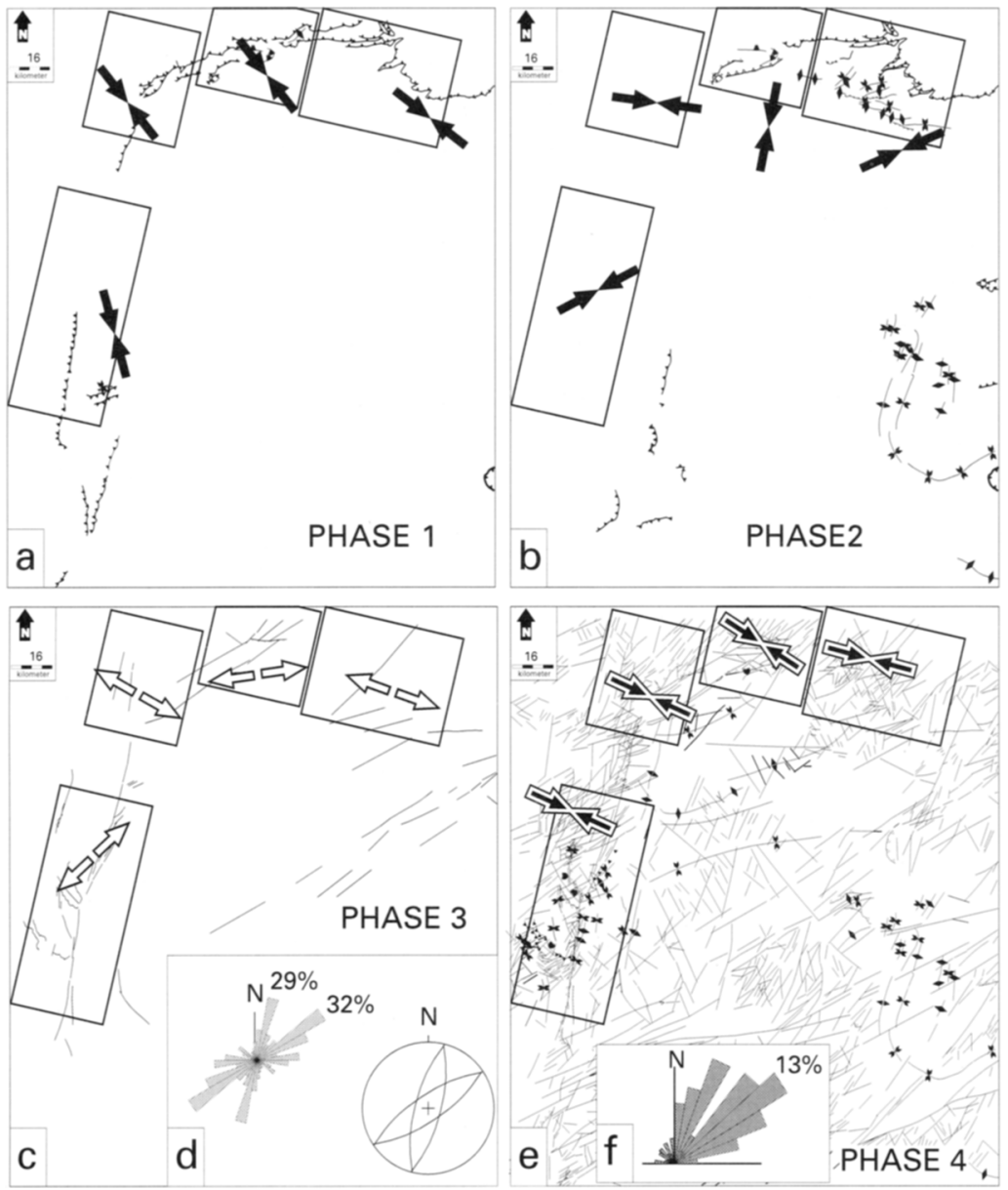

Fig. 10. Plot of horizontal components of $\sigma_{1}$ for phases 1,2 and 4 (converging large arrows) and $\sigma_{3}$ for Phase 3 (diverging large arrows), and for the structures proposed to have developed in a corresponding phase [(a)-(c) and (e)]. (d) Length-weighted rose diagram prepared from the faults proposed to have developed in deformation Phase 3 and an idealized stereographic projection of largest populations (note that they display two sets of conjugate faults). (f) Length-weighted rose diagram prepared from the faults proposed to have developed in deformation Phase 4.

ascribed to this deformation phase are obtained mainly from Lower to Middle Miocene units in subarea 4 . In other subareas they overprint the slickenlines that were previously ascribed to older phases and overprinted by the latest phase. Therefore, an Early-Middle Miocene age is assigned to this phase. The lengthweighted rose diagram (Fig. 10d), prepared from the normal faults supposedly developed in this deformation phase, indicates two sets of conjugate pairs of normal faults. Considering the oblique nature of the principal stresses discussed above, it is proposed that these faults are developed in so-called 'tri-axial strain conditions', which assumes that $\sigma_{1}$ is subvertical and other stresses are oblique to the horizontal plane (Reches 1978a, b; Krantz 1988).

\section{Phase 4}

This phase is characterized by strike-slip deformation in which $\sigma_{2}$ is subvertical and $\sigma_{1}$ and $\sigma_{3}$ are subhorizontal. The orientations of $\sigma_{1}$ trends are relatively consistent in the subareas and trend west-northwest with $17^{\circ}$ of overall discrepancy (Fig. 9d). In Fig. 10e the structures 

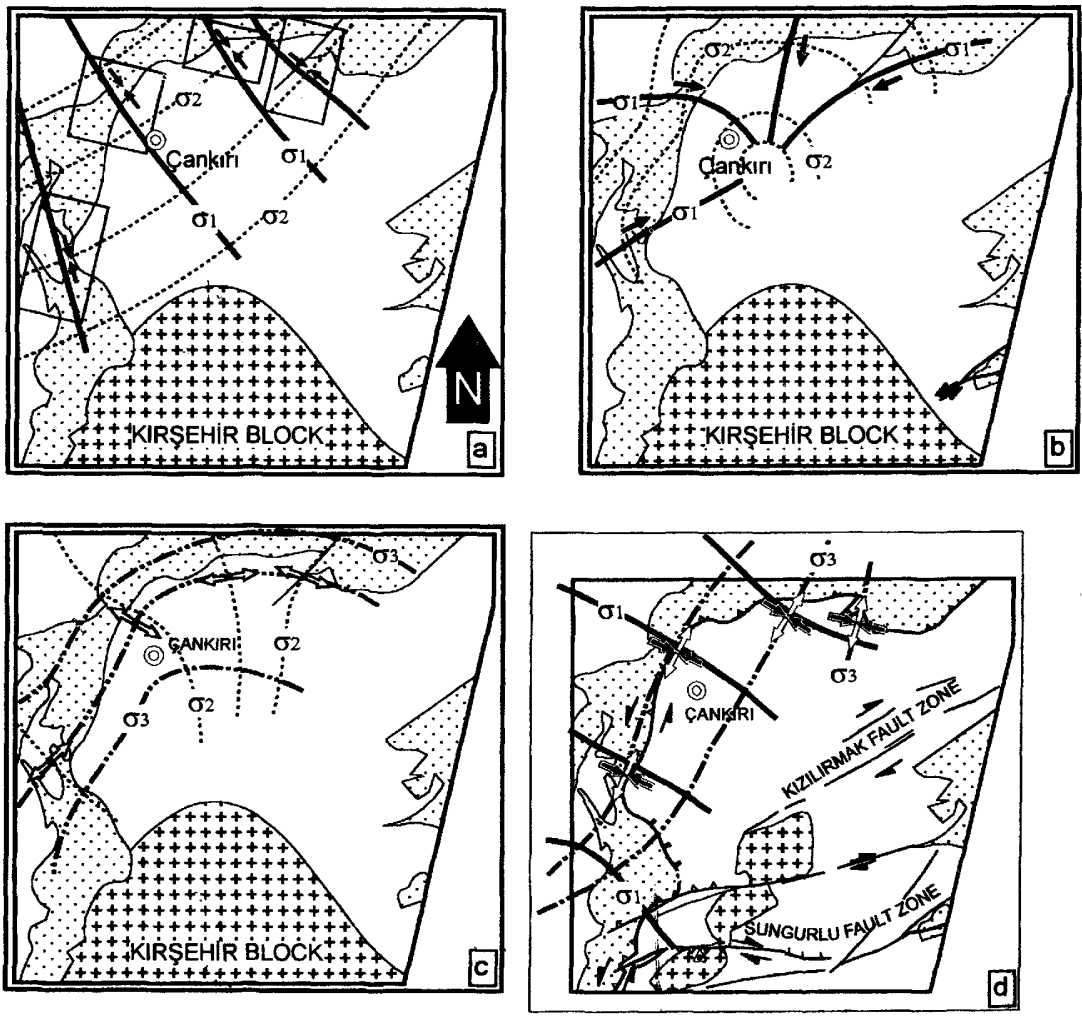

Fig. 11. Interpreted and smoothed stress trajectories for each deformation phase. (a) Phase 1; (b) Phase 2; (c) Phase 3; (d) Phase 4.

that may have developed in this phase are illustrated. It is obvious that most of these structures were reactivated in this deformation phase along inherited planes of weaknesses, although the variation of $\sigma_{1}$ between subareas is almost negligible. This relationship indicates that pre-existing planes of weakness do not play a major role in the stress-inversion procedure. The slip data attributed to this phase include the latest overprinting slickensides and the data collected from the faults that affected the Upper Miocene and younger units; therefore, a post-Middle Miocene age is assigned to this phase.

\section{Stress trajectories and the models}

Using the subarea-based principal stresses, smoothed stress trajectories of each phase are plotted (Fig. 11). The stress trajectories in Phase 1 display a mesh-like pattern in which the $\sigma_{1}$ trajectories are oriented northwest-southeast while $\sigma_{2}$ trajectories are curvilinear and convex southeastwards (Fig. 11a). In Phase 2 they display radial $\sigma_{1}$ and concentric $\sigma_{3}$ patterns (Fig. 11b). In deformation Phase 3, the $\sigma_{2}$ trajectories display radial pattern while $\sigma_{2}$ are concentric around the rim of the Çankırı Basin and exposed parts of the Kirşehir Block (Fig. 11c). The concentric pattern of $\sigma_{3}$ trajectories in deformation Phase 3 indicates uniaxial extension (Carey \& Bruner 1974) which is characteristic for areas of regional doming (Means 1976) and multidirectional extension (Arlegui-Crespo \& Simon-Gomez 1998). In deformation Phase 4, $\sigma_{1}$ and $\sigma_{3}$ trajectories display a mesh like pattern oblique to the western and northern rim, and to the Kizilirmak and Sungurlu Fault Zones (Fig. 11d).

The subduction of Neotethys took place northwards under the Pontides along a roughly east-west trending trench (Şengör \& Yilmaz 1981; Görür et al. 1984; Koçyiğit et al. 1988; Koçyiğit 1991; Dellaloğlu et al. 1992) in Late Cretaceous-Early Tertiary time, i.e. during deformation Phase 1. Considering the east-west oriented zone of convergence, the orientation of $\sigma_{1}$ (in Phase 1) is therefore oblique to the 

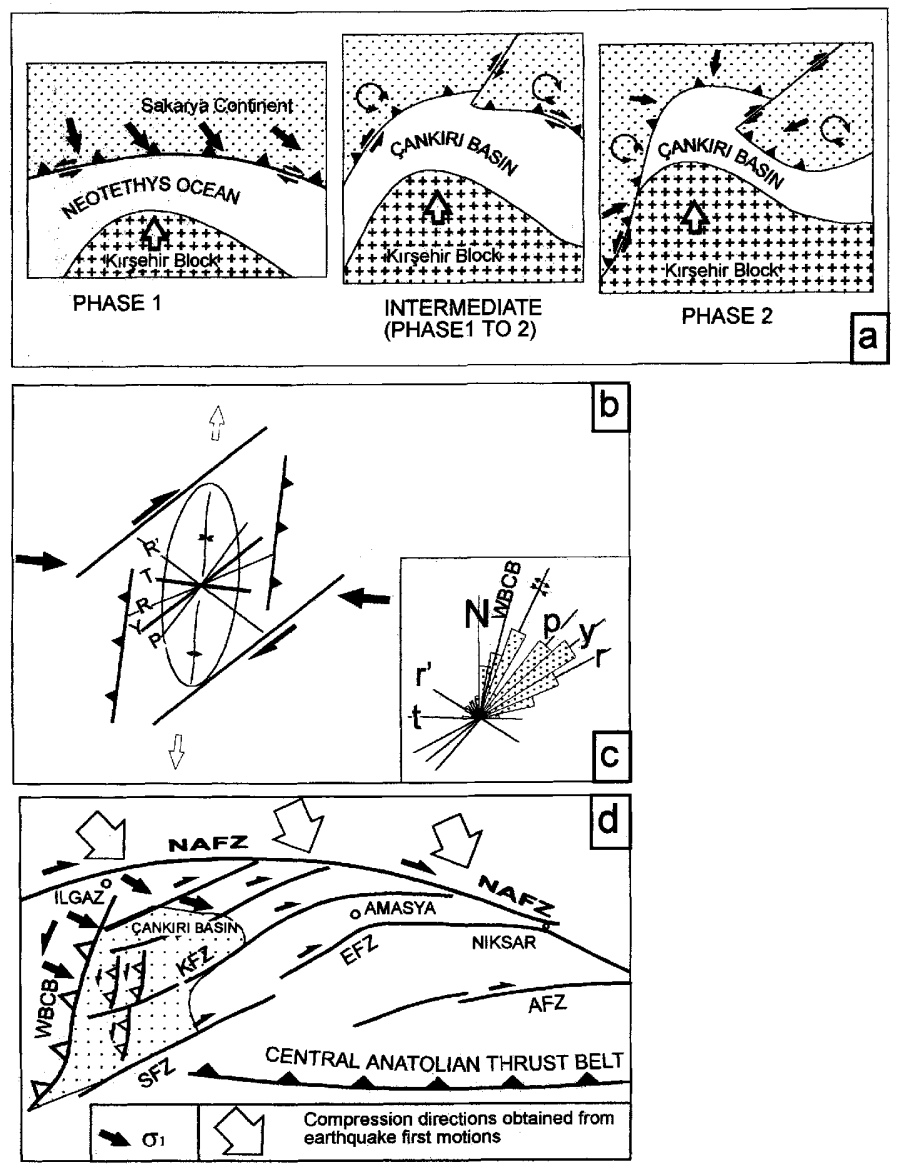

Fig. 12. (a) Cartoons illustrating the possible development of the Cankırı Basin through deformation Phases 1 and 2. Note block rotations and the response of principal stress orientations as the Kırşehir Block drives northwards. Black arrows are $\sigma_{1}$; white arrows are the relative movement sense of the Kırşehir Block (Pontides assumed fixed). (b) Riedel pattern of deformation [after Biddle \& Christie-Blick (1985)] and a plot of horizontal components of $\sigma_{1}$ (convergent large arrows) proposed to explain the structures developed in deformation Phase 4. (c) Length-weighted rose diagram prepared from the structures proposed to have developed in this phase and corresponding Riedel shears - $r$, primary synthetics shear; $r^{\prime \prime}$, antithetic shear; $p$, secondary synthetic shear; $y$, principal displacement zone; $t$, extensional structures. (d) Schematic illustration of the structures in north-central Turkey plotted to explain the structural development of the Çankırı Basin in deformation Phase 4 - AFZ, Almus Fault Zone; EFZ, Ezinepazarı Fault Zone; KFZ, Kızılırmak Fault Zone; NAFZ, North Anatolian Fault Zone; WBCB, western boundary fault of the Çankırı Basin [modified after Şengör et al. (1985)].

direction of convergence (Fig. 12a). This relationship may indicate that subduction had a dextral strike-slip component in this part of the Tethys Ocean (Fig. 12a), where the Sakarya continent and the Kırşehir Block eventually collided and amalgamated. Palaeomagnetic studies undertaken separately indicate that the western part of the Cankırı Basin rotated c. $30^{\circ}$ anticlockwise, while the eastern margin rotated $c .50^{\circ}$ clockwise, which resulted in the $\Omega$ shape of the basin in Eocene-Oligocene times.
This relationship may also be the reason for the radial $\sigma_{1}$ pattern and concentric $\sigma_{2}$ pattern developed with $\sigma_{3}$ subvertical in deformation Phase 2 (Fig. 11b).

In the Early Miocene, the collision and further convergence of the Sakarya continent and the Kırșehir Block was completed. Subsequently, the compressional regime was replaced by an extensional regime (in deformation Phase 3), which may be due to gravitational collapse (Dewey 1988). This gave rise to 
the formation of multidirectional normal faulting and the deposition of the Aslantas, Hancilı and Çandır Formations within graben complexes. Extensional deformation, driven by gravitational collapse, has already been postulated for western Turkey and the Aegean area (Seyitoğlu et al. 1992; Bozkurt \& Park 1994, 1997; see Lips 1998 and Walcott 1998 for Aegean references). Therefore, it can be proposed that Early-Middle Miocene extension in western Anatolia extended as far east as the Çankırı Basin area in central Turkey.

Having $\sigma_{2}$ subvertical and $\sigma_{1}$ oriented northwest-southeast during Phase 4 , indicates that the Sungurlu (SFZ) and Kizilırmak Fault Zones (KFZ) have been the two major strikeslip faults which deformed the Çankırı Basin and displaced its rims dextrally. The lengthweighted rose diagrams, prepared from these structures, indicate the dominance of northeasterly trends which display a Riedel deformation pattern (Figs 10f, 12b and c), which commonly develops in regions of regional transcurrent deformation and along strike-slip fault zones (Biddle \& Christie-Blick 1985). During this phase, the western margin of the basin reactivated as a sinistral strike-slip fault zone as the conjugate of the KFZ and the SFZ. As the western margin was dominated by a preexisting thrust fault belt, it was reactivated into a zone of sinistral transpression (Fig. 12d). In addition, the orientations of the constructed principal stresses (Fig. 12d) are parallel to the compressive and tensile axes obtained from recent earthquakes along the NAFZ (Jackson \& McKenzie 1984; Dewey et al. 1986). This relationship is consistent with the results given here.

\section{Conclusions}

- Four deformation phases have been recognized and their palaeostress configurations are constructed.

- The first phase is characterized by northwestsoutheast oriented $\sigma_{1}$ and subvertical $\sigma_{3}$, indicating compressional deformation characterized by thrusting.

- The second phase is characterized by radial $\sigma_{1}$ and concentric $\sigma_{2}$ patterns with subvertical $\sigma_{3}$, indicative of thrusting.

- Concentric $\sigma_{3}$ and subvertical $\sigma_{1}$ are indicative of extensional deformation in the third deformation phase.

- The final phase is characterized by a northwest-southeast oriented $\sigma_{1}$ pattern with very little variation of $\sigma_{1}$ orientations between the subareas.
- The structures, which were active in each deformation phase, are plotted. The structures, which were active in the latest deformation phase, display a Riedel deformation pattern that is consistent with the strike-slip deformation that has been in operation since the Late Miocene in the area.

We thank J. Angelier and K. Hardcastle for supplying their software; Y. Özçelik, Y. Öztaş, H. de Bruijn, A. van der Meulen, E. Ünay and G. Saraç for their help in the field and the Neogene age determinations. C. Duermeijer is thanked for palaeomagnetics. We appreciate the constructive criticism of $\mathrm{K}$. Hardcastle, who twice reviewed early drafts of this paper. NK thanks A. Zanchi, who introduced Angelier's software. This work was conducted under the programme of the Vening Meinesz Research School of Geodynamics (VMSG). NK also received a grant from Kocaeli University, Izmit-Turkey, which is gratefully acknowledged. We thank R. J. Lisle and A. Koçyiğit for their constructive reviews of the manuscript.

\section{References}

AleXANDrowsKi, P. 1985. Graphical determination of principal stress directions for slickenside lineation populations: an attempt to modify Arthoud's method. Journal of Structural Geology, 7, 73-82.

ANGelier, J. 1979. Determination of the mean principal directions of stress for a given fault population. Tectonophysics, 56, T17-T26.

- 1984. Tectonic analysis of fault slip data sets. Journal of Geophysical Research, 89, 5835-5848.

1989. From orientation to magnitudes in palaeostress determination using fault slip data. Journal of Structural Geology, 11, 37-50.

1994. Fault slip analysis and palaeostress reconstruction. In: Hancock, N. L. (ed.) Continental Deformation. Pergamon Press, 53-100.

- Tarantola, A., Valette, B. \& Manoussis, S. 1982. Inversion of field data in fault tectonics to obtain the regional stress - 1 . Single phase fault populations: a new method of computing the stress tensor. Geophysical Journal of Royal Astronomical Society, 69, 607-621.

Arlegui-Crespo, L. E. \& Simon-Gomez, J. L. 1998. Reliability of palaeostress analysis from fault striations in near multidirectional extension stress fields. Examples from the Ebro Basin, Spain. Journal of Structural Geology, 20, 827-840.

Armijo, R., Carey, E. \& Cisternas, A. 1982. The inverse problem in microtectonics and the separation of tectonic phases. Tectonophysics, 82, 145169.

Arthaud, F. 1969. Méthode de détermination graphique des directions de reccourcissement d'allongement et intermédiare d'une population de failles. Bulletin de la Société Géologique de France 11, 739-757.

Barka, A. A. \& Hancock, P. L. 1984. Neotectonic deformation patterns in the convex-northwards 
arc of the North Anatolian Fault Zone. In: Dixon, J. E. \& Robertson, A. H. F. (eds) The Geological Evolution of the Eastern Mediterranean. Geological Society, London, Special Publications, 17, 763-774.

Biddle, K. T. \& Christie-Blick, N. 1985. Strike-slip Faulting and Basin Formation. Society of Economic Palaeontologists and Mineralogists, Special Publications, 37.

Botr, M. P. H. 1959. The mechanics of oblique-slip faulting. Geological Magazine, 96, 109-117.

BozkurT, E. \& KoçYiĞí, A. 1995. Almus Fault Zone: its age, total offset and relation to the North Anatolian Fault Zone. Turkish Journal of Earth Sciences, 4, 93-104.

\& _ 1996. The Kazova Basin: an active negative flower structure on the Almus Fault Zone, a splay fault system of the North Anatolian Fault Zone, Turkey. Tectonophysics, 265, 239254.

__ \& PARK, R. G. 1994. Southern Menderes Massif: an incipient metamorphic core complex in western Anatolia, Turkey. Journal of the Geological Society, London, 151, 213-216.

_ _ \& - 1997. Evolution of a mid-Tertiary extensional shear zone in the southern Menderes Massif, western Turkey. Bulletin de la Société Géologique de France, 168, 3-14.

Carey, E. \& Bruner, B. 1974. Analyse théorique et numérique d'une modèle méchanique élémenttaire appliqué a l'étude d'une population de failles. Comptes Rendus de l'Académie des Sciences de Paris, 279, 891-894.

Carey-Gailhardis, E. \& Mercier, J. L. 1987. A numerical method for determining the state of stress using focal mechanisms of earthquake populations: application to Tibetan teleseisms and microseismicity of southern Peru. Earth and Planetary Science Letters, 82, 165-179.

DellaloĞlu, A. A., Tüysüz, O., KaYA, İ. H. \& HaRput, B. 1992. Kalecik (Ankara)-EldivanYaprakll (Çankirl)-ískilip (Çorum) ve Devrez Cayı Arasındaki Alanin Jeolojisi ve Petrol Olanaklarl. Turkish Petroleum Corporation (TPAO) Report, No. 3194.

DeweY, J. F. 1977. Suture zone complexities: a review. Tectonophysics, 40, 53-67.

1988. Extensional collapse of orogens. Tectonics, 7, 1123-1139.

—, Hempton, M. R., Kidd, W. S. F., ŞaroĞLu, F. \& SENGöR, A. M. C. 1986. Shortening of continental lithosphere: the neotectonics of Eastern Anatolia - a young collisional zone. In: CowarD, M. P. \& Ries, A. C. (eds) Collision Tectonics. Geological Society, London, Special Publications, 19, 3-36.

Duphin, J. M, SAssi, W. \& Angelier, J. 1993. Homogeneous stress hypothesis and actual fault slip: a distinct element analysis. Journal of Structural Geology, 15, 1033-1043.

Etchecopar, A., Visseur, G. \& Daignieres, M. 1981. An inverse problem in microtectonics for the determination of stress tensors from fault striation analysis. Journal of Structural Geology, 3, 5165 .
Fleischman, K. H. \& NemcoK, M. 1991. Palaeostress inversion of fault-slip data using the shear stress solution of Means (1989). Tectonophysics, 196, 195-202.

Fleuty, M. J. 1974. Slickensides and slickenlines. Geological Magazine, 112, 319-322.

Gephart, J. W. 1990. Stress and direction of slip on fault planes. Tectonophysics, 8, 845-858.

— \& FoRSYTH, D. W. 1984. An improved method for determining the regional stress tensor using earthquake focal mechanism data: application to the San Fernando earthquake sequence. Journal of Geophysical Research, 89, 9305-9320.

Görür, N., OkTay, F. Y., SEymen, İ. \& S,Engör, A. M. C. 1984. Palaeotectonic evolution of the Tuzgölì Basin complex, central Turkey: sedimentary record of a Neotethyan closure. In: DixoN, J. E. \& Robertson, A. H. F. (eds) The Geological Evolution of the Eastern Mediterranean. Geological Society, London, Special Publications, 17, 8196.

Hancock, P. L. 1985. Brittle microtectonics: principles and practice. Journal of Structural Geology, 7, 437-457.

Hardcastle, K. C. 1989. Possible palaeostress tensor configurations derived from fault-slip data in eastern Vermont and eastern New Hampshire. Tectonics, 8, 265-284.

— \& Hills, L. S. 1991. BRUTE3 \& SELECT: QuickBasic 4 programs for determination of stress tensor configurations and separation of heterogeneous populations of fault-slip data. Computer and Geoscience, 17, 23-43.

JACKson, J. A. \& McKenzie, D. P. 1984. Active tectonics of the Alpine-Himalayan Belt between western Turkey and Pakistan. Geophysical Journal of the Royal Astronomical Society, 77, 185264.

KaYMaKçI, N. \& KoçYí̆ìt, A. 1995. Mechanism and basin generation in the splay fault zone of the North Anatolian Fault Zone. EUG-8 Abstracts.

KoçYiŏìt, A. 1991. An example of an accretionary forearc basin from north Central Anatolia and its implications for the history of subduction of Neotethys in Turkey. Geological Society of America Bulletin, 103, 22-36.

, Özkan, S. \& Rojay, B. 1988. Examples from the fore-arc basin remnants at the active margin of northern Neotethys; development and emplacement age of the Anatolian Nappe, Turkey. METU Journal of Pure and Applied Sciences, 21, 183-120.

Krantz, R.W. 1988. Multiple fault sets and threedimensional strain: theory and application. Journal of Structural Geology, 10, 225-237.

Lacombe, O., Angelier, J. \& Laurent, Рh. 1992. Determining palaeostress orientations from faults and calcite twins: a case study near the Sainte-Victoire Range (southern France). Tectonophysics, 201, 141-156.

Bergerat, F. \& Tourneret, C. 1990 Joint analysis of calcite twins and fault slips as a key for deciphering polyphase tectonics: Burgundy as a case study. Tectonophysics, 202, 83-93. 
LIPS, A. L. W. 1998. Temporal constraints on the kinematics of the destabilisation of an orogen: syn- to post-orogenic extensional collapse of the northern Aegean region. PhD Thesis, Utrecht University (166).

Marret, R. \& Almandinger, R. W. 1990. Kinematic analysis of fault slip data. Journal of Structural Geology, 12, 973-986.

Means, W. D. 1976. Stress and Strain. Springer.

Michael, A. J. 1984. Determination of stress from slip data: faults and folds. Journal of Geophysical Research, 89, 11517-11526.

NemcoK, M. \& LisLe, R. J. 1995. A stress inversion procedure for polyphase fault/slip data sets. Journal of Structural Geology, 17, 1445-1453.

Nieto-Samaniego, A. F. \& Alaniz-Alvarez, S. A. 1997. Origin and tectonic interpretation of multiple fault patterns. Tectonophysics, 270, 197-206.

OKAY, A. İ. 1984. Distribution and characteristics of the northwest Turkish blueschists. In: Dixon, J. E. \& Robertson, A. H. F. (eds) The Geological Evolution of the Eastern Mediterranean. Geological Society, London, Special Publications, 17, 429-440.

ÖzçELİ, Y. 1994. Tectono-stratigraphy of the Laçin area (Çorum - Turkey). MSc Thesis, Middle East Technical University.

Pasquare, G., Poli, S., Vezzoli, L. \& Zanchi, A. 1988. Continental arc volcanism and tectonic setting in Central Anatolia, Turkey. Tectonophysics, 146, 217-230.

Pollard, D. D., Saltzer, S. D. \& Rubin, A. M. 1993. Stress inversion methods: are they based on faulty assumptions? Journal of Structural Geology, 15, 1045-1054.

Reches, Z. 1978a. Analysis of faulting in threedimensional strain field. Tectonophysics, 47, 109 129.

$1978 b$. Faulting of rocks in three-dimensional strain field - II; theoretical analysis. Tectonophysiscs, 95, 133-156.

- 1987. Determination of the tectonic stress tensor from slip along faults that obey the Coloumb yield creterion. Tectonics, 6, 849-861.

RoJAY, B. 1993. Tectonostratigraphy and neotectonic characteristics of the southern margin of Merzifon-Suluova Basin (Central Pontides, Amasya). PhD Thesis, Middle East Technical University. 1995. Post-Triassic evolution of Central Pontides: evidence from Amasya region, Northern Anatolia. Geologica Romana, 31, 329-350.

ȘENGör, A. M. C. \& YIlmaz, Y. 1981. Tethyan evolution of Turkey: a plate tectonic approach. Tectonophysics, 75, 181-241.

—, ŞARoĞLU, F. \& GörÜR, N. 1995. Strike-slip deformation and related basin formation in zones of tectonic escape: Turkey as a case study. In: Biddle, K.T. \& Blick, N.C. (eds) Strike-slip Deformation, Basin Formation and Sedimentation. Society of Economic Palaeontologists and Mineralogists, Special Publications, 37, 227-264. , Yilmaz, Y. \& Sungurlu, O. 1984. Tectonics of the Mediterranean Cimmerides: nature and evolution of the western termination of PalaeoTethys. In: Dixon, J. E. \& Robertson, A. H. F. (eds) The Geological Evolution of the Eastern Mediterranean. Geological Society, London, Special Publications, 17, 77-112.

SeyitoĞLu, G., Scot, B. \& Rundle, C. 1992. Timing of Cenozoic extensional tectonics in west Turkey. Journal of the Geological Society, London, 149, 533-538.

Tankut, A., SATiR, M., Güleç, N. \& TopraK, V. 1995. Galatya Volkaniklerinin Petrojenezi. TÜBİTAK Project No. YBAG-0059 [in Turkish with English abstract].

Toprak, V., Savaşçin, Y., Güleç, N. \& Tankut, A. 1996. Structure of the Galatean Volcanic Province, Turkey. International Geology Review, 38, 747-758.

TwISs, R. J. \& UNRUH, J. R. 1998. Analysis of fault slip inversion; do they constrain stress or strain rate? Journal of Geophysical Research, 103, 12 20512222

WalcotT, C. R. 1998. The Alpine evolution of the Thessaly (NW Greece) and Late Tertiary kinematics. PhD Thesis, Utrecht University (162).

WALLACE, R. E. 1951. Geometry of shearing stress and relation to faulting. Journal of Geology, 69, 118130.

WILL, T. M. \& Powell, R. 1991. A robust approach to the calculation of palaeostress fields from fault plane data. Journal of Structural Geology, 13, 813-821.

YIN, Z. M. \& RaNALli, G. 1993. Determination of tectonic stress field from fault slip data, toward a probabilistic model. Journal of Geophysical Research, 98, 12165-12176. 